\title{
The Ordovician ostracodes established by Aurel Krause, Part I
}

\author{
Roger Schallreuter* and Ingelore Hinz-Schallreuter \\ Institut für Geographie und Geologie, Ernst Moritz Arndt-Universität, Friedrich Ludwig Jahn-Str. 17a, 17489 Greifswald, Germany. \\ E-mail: Roger.Schallreuter@uni-greifswald.de; ihinz-s@uni-greifswald.de
}

\begin{abstract}
Received 27 April 2010

Accepted 14 September 2010

Published 21 February 2011

\section{Key Words}

Baltoscandia

glacial erratic boulders

Northern Germany

revisions

synonyms

The lack of a revision of the ostracodes described by Aurel Krause at the end of the 19th century from glacial erratic boulders from Berlin and the Mark Brandenburg (Northern Germany) has led to taxonomic confusion in the corresponding literature of the 20th century. To attain stability in names, some of Krause's ostracode species have been revised based on the types stored in the Museum für Naturkunde Berlin, namely Primitia plana, P. plana tuberculata, P. intermedia, P. globifera, Entomis sigma antiquata, Bollia v-scripta, B. granulosa, B. duplex, Strepula lineata, Isochilina canaliculata, Beyrichia dissecta, B. mamillosa, B. signata, and B. bidens. Most species have up to four younger synonyms among species described later from outcrops or borings in Baltoscandia or glacial erratic boulders of Northern Germany and Sweden. Three of Krause's species, which have been considered as nomina dubia by Jaanusson are in fact valid species. Some of Krause's species or of their synonyms are type species.
\end{abstract}

\section{Introduction}

Systematic descriptions of Ordovician ostracodes from Baltoscandia have been started by the end of the 19th century with Aurel Krause. Between 1889 and 1897 he described in several papers new ostracodes from glacial erratic boulders from Berlin and the Mark Brandenburg. Before him, only few ostracode species were sporadically established by Eichwald (1854, 1860), F. Schmidt (1858), Bock (1867), Linnarsson (1869), and Brögger (1882). Apart from Bonnema's (1909) and Öpik's (1937) monographs on the ostracodes of the Uhaku and Kukruse stages of Estonia and few other but small papers, the main investigations on Ordovician ostracodes from Baltoscandia took place not before the end of the war (Henningsmoen 1948, 1953a, 1954a, 1954b; Neckaja 1952, 1953, 1958, 1966, 1973; Stumbur 1956; Jaanusson 1957, 1966; Sarv 1959, 1962, 1963; Thorslund 1940, 1948). However, these papers clearly document the utmost necessity of a modern revision of the ostracodes described by Krause at the end of the 19th century.

It has been generally assumed that the types of the species described by Krause formerly belonging to the Geologisch-Paläontologisches Museum of the Friedrich Wilhelm-Universität Berlin were lost during the war
(Jaanusson 1962, 412). However, in 1958 the material was returned from the former Soviet Union to Berlin and has been housed in the Paläontologisches Museum der Humboldt Universität (Diebel 1960), now Museum für Naturkunde Berlin.

Enabled by a loan of Krause's types to Uppsala, Valdar Jaanusson started a revision of Krause's Ordovician ostracods at the beginning of the sixties. In 1962 Jaanusson published a short note on these ostracodes in which he cited nine species with their younger synonyms described from the Baltoscandian Ordovician and four species of Krause which he considered as nomina dubia (Tab. 1). Two of these species were refigured by Jaanusson in his 1966 paper. Further revisions were never published by Jaanusson and by the end of the nineties the unrevised material came back to Berlin. Only some photos taken by Jaanusson have been made availabe to some colleagues.

Therefore, a new attempt for part of Krause's material was made by the present authors (Schallreuter \& Hinz-Schallreuter 2005) in order to attain stability in taxonomic determinations since many species have up to several younger synonyms. In the frame of their revisions the authors also revealed wrong interpretations of some of Krause's species.

\footnotetext{
* Corresponding author
} 
Table 1. The species of Krause studied by Jaanusson (1962) and their synonyms. G - no. of Krause's glacial erratic boulders with the type specimen; H - Hessland; ** - valid as subspecies. [1] - Jaanusson (1962); [2] - Jaanusson (1966); [3] Jaanusson (1957); [4] - Schallreuter (1993); [5] - Schallreuter (1985).

\begin{tabular}{|c|c|c|c|c|c|}
\hline Krause's species & year & $\mathrm{G}$ & actual combination & synonyms (*no more, see Table 2) & reference \\
\hline Primitia bursa & 1889 & 292 & Euprimites b. & Euprimites bursellus Jaanusson, 1957 & [1] p. 412 \\
\hline P. sulcata & 1889 & 315 & Conchoprimitia s. & Primitia tolli Bonnema, 1909 & [1] p. 412 \\
\hline Beyrichia digitata & 1889 & 303 & Glossomorphites $d$. & $\begin{array}{l}\text { Glossopsis clavata H., } 1949 \\
\text { Glossopsis lingua H., } 1949 \\
\text { **Entomis impressa Steusloff, } 1895\end{array}$ & $\begin{array}{l}\text { [1] p. } 412 \\
\text { [1] p. } 412 \\
\text { [4] p. } 89\end{array}$ \\
\hline B. marchica angustata & 1891 & 150 & Tallinnella a. & Tallinnella dimorpha Öpik, 1937 & [1] p. 413 \\
\hline B. erratica acuta & 1891 & 479 & Asteusloffia a. & $\begin{array}{l}\text { Steusloffia polynodulifera } \\
\text { Hessland, } 1949\end{array}$ & [1] p. 413 \\
\hline Isochilina ? erratica & 1891 & 400 & Conchoprimitia e. & $\begin{array}{l}\text { Conchoides circumstriatus } \\
\text { Hessland, } 1949\end{array}$ & [1] p. 412 \\
\hline Primitia labrosa & 1892 & 497 & Uhakiella I. & $\begin{array}{l}\text { Uhakiella aequigranosa } \\
\text { Jaanusson, } 1957\end{array}$ & [1] p. 413 \\
\hline Entomis auricularis & 1892 & 587 & Disulcinoides a. & Sigmobolbina quanta Sarv, 1959 & [1] p. 413 \\
\hline Bollia major & 1892 & 670 & Bolbina $m$. & $\begin{array}{l}\text { Bolbina lehtmetsaensis Sarv, } 1959 \\
\text { Bollia minor Krause, } 1892 \\
\text { Bolbina major calva } \\
\text { Schallreuter, } 1987\end{array}$ & $\begin{array}{l}\text { [1] p. } 413 \\
\text { [5] p. } 104\end{array}$ \\
\hline Beyrichia carinata & 1892 & 670 & Carinobolbina $c$. & Carinobolbina estona magnifera Sarv, 1959 & $\begin{array}{l}\text { [1] p. } 413 \\
\text { [2] p. } 29\end{array}$ \\
\hline Beyrichia rostrata & 1892 & 587 & Sigmoopsis $r$. & Sigmoopsis lamina Sarv, 1959 & $\begin{array}{l}\text { [1] p. } 413 \\
\text { [2] p. } 29\end{array}$ \\
\hline Primitia cincta & 1889 & & Eobromidella c. & $\begin{array}{l}\text { Eobromidella sp. indet. } \\
\text { nom. dub. }\end{array}$ & [1] p. 413 \\
\hline Primitia intermedia & 1889 & 339 & Euprimites $i$. & $\begin{array}{l}\text { Euprimites sp. indet. } \\
\text { nom. dub.* }\end{array}$ & [1] p. 413 \\
\hline Strepula lineata & 1889 & 106 & Steusloffia I. & $\begin{array}{l}\text { Steusloffia sp. indet. } \\
\text { nom. dub.* }\end{array}$ & [1] p. 413 \\
\hline Primitia globifera & 1892 & 666 & Hesperidella g. & $\begin{array}{l}\text { Hesperidella sp. indet. } \\
\text { nom. dub.* }\end{array}$ & $\begin{array}{l}\text { [3] p. } 329 \\
\text { [1] p. } 413\end{array}$ \\
\hline
\end{tabular}

\section{Material}

Krause's material came from glacial erratic boulders of both Berlin region and Mark Brandenburg. Most of the samples were collected in the former sand and gravel pits near Müggelheim at the Müggel Isle (Berlin) (Krause 1889: 22). They came from different glacial erratic boulders which Krause (1889: 24) called "Untersilurischer Beyrichienkalk" (Ordovician Beyrichia Limestone) - an unsuitable name because the term refers to many types of Middle and Upper Ordovician limestone glacial erratic boulders of Baltoscandia (Kummerow 1924: 409; Schallreuter 1993: 13-14). A second group of ostracodebearing glacial erratic boulders Krause (1892: 399) called "Geschiebe mit Beyrichia rostrata" (glacial erratic boulders with Sigmoopsis rostrata). From this group he described a complete ostracode fauna so that this type is better characterized faunistically. This fauna was found several years ago in a boulder from Münsterland which allowed its revision (Schallreuter 1985). However, for political reasons the types had not been available for the author at that time.

Most of the species revised herein came from different boulders (Tab. 2). Only three of these species orginate from one boulder (no. 670) of the so-called "rostrata" type group. Stratigraphically, the boulder was referred to as the Keila Stage (D2) (Schallreuter 1976: 164). Later, the group to which this boulder belongs was called "Har- pakalk" (Schallreuter 1985: 101). It is assumed to originate from the northern Middle Baltic Sea (Schallreuter 1985: 102). The age of the other glacial erratic boulders could be gained from the stratigraphical occurrences of the synonyms of the respective species.

Many of the figured specimens of Krause's ostracodes were stored in small glass tubes together with a small label inside the tube. The tubes were kept together with some labels in open boxes.

Some of the ostracodes were glued on the cork of the tube. This fact combined with the coating with $\mathrm{MgO}$ for previous photography badly affected the respective specimens.

The oldest labels seem to be those inside the glass tubes. However, they could not be from Krause himself, because such tubes and labels are used also for few of Kummerow's (1924) species in the museum's collection. The label without an institutional assignment (only: Inv. Geol. S.) were probably labels of the former Märkisches Museum or Geologisches Landesmuseum Berlin. The $3^{\text {rd }}$ labels are from the "Geol.-Paläont. Mus. Berlin". Many types have a $4^{\text {th }}$ label from Jaanusson - but mostly without further information.

If not stated otherwise the glacial erratic boulders with the types of the Krause's species came from the type locality, the former gravel/ sand pits near Müggelheim on Müggel Isle (Berlin), $52^{\circ} 25^{\prime} \mathrm{N}$, $31^{\circ} 19^{\prime} \mathrm{E}$.

Palaeontological dating of glacial erratic boulders is generally only possible if their fossil content is also known from Baltoscandian out- 
Table 2. The species of Krause revised in this paper and their synonyms. Type species are set in bold face. G=no. of Krause's glacial erratic boulders with the type specimen; T. - Thorslund; Ö - Öpik 1937; [1] - Schallreuter \& Hinz-Schallreuter 2008; [2] - Bassler \& Kellett 1934; [3] - Schallreuter 1995; [4] - Henningsmoen 1954; [5] - Sarv in Kaljo et al. 1956; [6] - Sarv 1959; [7] - Schallreuter 1973; [8] - Schallreuter 1968.

\begin{tabular}{|c|c|c|c|c|c|}
\hline Krause's species & year & G & actual comb. & synonyms (*valid as subspecies) & reference \\
\hline Primitia plana & 1889 & 301 & Tvaerenella plana & $\begin{array}{l}\text { Primitiella umbilicata Kummerow, } 1924 \\
\text { Tvaerenella expedita Sarv, } 1959\end{array}$ & $\begin{array}{l}\text { this paper } \\
\text { [1] p. } 809\end{array}$ \\
\hline Beyrichia signata & 1892 & 648 & Signakiella signata & $\begin{array}{l}\text { Strepula signata Steusloff, } 1895 \\
\text { Signakiella steusloffi Schallreuter, } 1988 \\
\text { Steusloffia wandae Sztejn, } 1989 \\
\text { Piretella? paczerensis Sidaravičienè, } 1992\end{array}$ & $\begin{array}{l}\text { [2] p. } 476 \\
\text { Schallreuter } 1988 \text {, p. } 40 \\
\text { [3] p. } 128 \\
\text { Sidaravičiené } 1996 \text {, p. } 16\end{array}$ \\
\hline Beyrichia dissecta & 1892 & 616 & Kiesowia dissecta & $\begin{array}{l}\text { Kiesowia septenaria Stumbur, } 1956 \\
\text { *Hithis leviconvexus Schallreuter, } 1967\end{array}$ & $\begin{array}{l}\text { [4] p. } 79 \text { (?) } \\
\text { Meidla 1996, p. } 57 \\
\text { Sarv 1962, p. } 109 \\
\text { Meidla 1996, p. } 57\end{array}$ \\
\hline Bollia v-scripta & 1889 & 112 & Vauscripta $v$-scripta & $\begin{array}{l}\text { Piretella tridactyla Jaanusson, } 1957 \\
\text { Mojczella jaanussoni Olempska, } 1989\end{array}$ & $\begin{array}{l}\text { this paper } \\
\text { Sidaravičienè 1992, p. } 147\end{array}$ \\
\hline Primitia intermedia & 1889 & 339 & $\begin{array}{l}\text { Euprimites } \\
\text { intermedius }\end{array}$ & Euprimites locknensis Thorslund, 1940 & this paper \\
\hline $\begin{array}{l}\text { Primitia plana } \\
\text { tuberculata }\end{array}$ & 1892 & 670 & $\begin{array}{l}\text { Tvaerenella } \\
\text { tuberculata }\end{array}$ & $\begin{array}{l}\text { Primitiella indistincta Öpik, } 1937 \\
\text { Primitiella granosa Öpik, } 1937 \\
\text { Primitiella carinata T., } 1940\end{array}$ & $\begin{array}{l}{[5] \text { p. } 51,[6] \text { p. } 30} \\
\text { this paper } \\
\text { [7] p. } 104\end{array}$ \\
\hline Isochilina canaliculata & 1892 & 670 & $\begin{array}{l}\text { Oepikella } \\
\text { canaliculata }\end{array}$ & $\begin{array}{l}\text { Macronotella bonnemai Ö., } 1937 \\
\text { Oepikella tvaerensis T., } 1940 \\
\text { Oepikella asklundi T., } 1940 \\
\text { Tvaerenella stossmeisteri Schallreuter, } 1985\end{array}$ & $\begin{array}{l}\text { this paper } \\
\text { this paper } \\
\text { [7] p. } 271 \\
\text { this paper }\end{array}$ \\
\hline $\begin{array}{l}\text { Entomis sigma } \\
\text { antiquata }\end{array}$ & 1891 & 187 & $\begin{array}{l}\text { Oepikium } \\
\text { antiquatum }\end{array}$ & & \\
\hline Strepula lineata & 1889 & 106 & Asteusloffia lineata & Strepula lineata granulosa Steusloff, 1895 & this paper \\
\hline Bollia granulosa & 1889 & 339 & Uhakiella granulosa & $\begin{array}{l}\text { Beyrichia granulifera UIrich \& Bassler, } 1908 \\
\text { ? *Uhakiella coelodesma Ö. }\end{array}$ & $\begin{array}{l}\text { Ulrich \& Bassler 1908, p. } 285 \\
\text { this paper }\end{array}$ \\
\hline Beyrichia bidens & 1892 & 670 & Bilobatia bidens & *Bilobatia serralobata Schallreuter, 1976 & Schallreuter 1982, p. 9,15 \\
\hline Bollia duplex & 1892 & 640 & Duplexi bollia $d$. & & \\
\hline Primitia globifera & 1892 & 666 & Balticella globifera & $\begin{array}{l}\text { Primitia binodis Krause, } 1897 \\
\text { Balticella oblonga T., } 1940\end{array}$ & $\begin{array}{l}\text { this paper } \\
\text { [8] p. } 135\end{array}$ \\
\hline
\end{tabular}

crops or borings. When Krause described his new species the knowledge of Ordovician ostracode faunas from Baltoscandian outcrops was still very limited, and apart from the types none of Krause's glacial erratic boulders material has been preserved. Therefore, dating of Krause's stratigraphically unassigned ostracode types results from synonymous species of outcrops. Some of Krause's newly established ostracodes lacking later synonyms may be datable by associated ostracodes mentioned already by Krause and whose occurrence is meanwhile known from outcrops. A third possibility for dating is the use of comparative material from exactly dated glacial erratic boulders.

Abbreviations. C1, C2, C3, C4 - cristae (on or originating from corresponding lobes); GG - Institut für Geographie und Geologie, Ernst Moritz Arndt-Universität Greifswald; H - height; IGT - Institute of Geology, University Tartu; L - length; L1, L2, L3, L4 - lobes 1-4; MB. - Museum für Naturkunde Berlin; OD - original designation; PAN - preadductorial node; SD = subsequent designation; SGU Sveriges Geologiska Undersökning Stockholm; syn. (in the lists of synonyms) - q.v. for further synonymy.

Definition of size. $<0.50 \mathrm{~mm}$ very small; $0.50-1.00 \mathrm{small} ; 1.00-2.00$ median-sized; 2.00-5.00 large.

Since the scales of the plates based on SEM data may deviate a little, the absolute size is given in the explanations. Because of the fixed position of the SE-detector in the SEM (which corresponds to the lamp in light photography) two views orientated perpendicularly to each other have been figured from the specimen in Figure 3A.

\section{Systematic Palaeontology}

Order Palaeocopa Henningsmoen, 1953

Suborder Beyrichiomorpha Henningsmoen, 1965

Superfamily Eurychilinoidea Ulrich \& Bassler, 1923

Family Oepikellidae Jaanusson, 1957

Subfamily Oepikellinae Jaanusson, 1957

\section{Oepikella Thorslund, 1940}

Type species. Öpikella tvaerensis Thorslund, 1940; by original designation.

= Isochilina canaliculata Krause, 1889 = Macronotella bonnemai Öpik, $1937=$ Oepikella asklundi Thorslund, $1940=$ Tvaerenella stossmeisteri Schallreuter, 1985.

Definition. Jaanusson 1957: 270. 


\section{Oepikella canaliculata (Krause, 1892)}

\section{Figure 1A}

1892 Isochilina canaliculata Krause: 385, 399, pl. 21, figs 1a-b. non 1897 Isochilina cf. canaliculata. - Krause: 932, 938, pl. 25, fig. 15 (= Tvaerenella ? sp.).

1934 Aparchites canaliculatus. - Bassler \& Kellett: 55, 157, 338.

1937 Macronotella bonnemai Öpik: 5, 23, 60, 69, 87, 124, pl. 1, figs 7-8.

1940 Öpikella tvaerensis Thorslund: 181-182, 187, pl. 2, figs 1-7. 1940 Öpikella canaliculata. - Thorslund: 181, 182.

1940 Öpikella bonnemai. - Thorslund: 181.

1940 Öpikella asklundi Thorslund: 182, 187, pl. 1, figs 3-5.

1957 Oepikella tvaerensis. - Jaanusson: 270, 271-275, tabs 11, 40, figs 8, 19-20, pl. 4, figs 9-19, pl. 13, figs 1-13 (syn.).

1959 Oepikella bonnemai. - Sarv: 15-16, tab. 2, pl. 2, figs 12-13 (= Öpik 1937, pl. 1, figs 7a-b).

1979 Oepikella bonnemai. - Ivanova: 73, 187, pl. 5, fig. 3.

1985 Oepikella canaliculata. - Schallreuter: 102, 134, tab. 1, pl. 3, fig. 5 , pl. 8 , fig. 1 .

1985 Tvaerenella stossmeisteri Schallreuter: 107-108, 124, tab. 1, pl. 3, fig. $4 \mathrm{a}-\mathrm{b}$.

1990 Oepikella tvaerensis. - Ivanova in Abushik et al.: 56, 232, pl. 6, fig. 2 .

1990 Oepikella? canaliculata. - Hints et al. in Aru et al.: 138, fig. 30 (cf.; faunal $\log$ ).

Lectotype (designated here). Juvenile left tecnomorphic valve, MB. HS 2010-9, Figure 1A, Krause 1892, pl. 21, fig. 1.

Type locality and horizon. Müggelheim; Krause's glacial erratic boulder no. 670 , age Keila (D2).

Dimensions. Lectotype L $1.98 \mathrm{~mm}, \mathrm{H} 1.32 \mathrm{~mm}$. The largest specimen measured by Jaanusson (1957, tab. 11) reaches $3.61 \mathrm{~mm}$, i.e. the lectotype is not adult.

Definition. At least up to $3.61 \mathrm{~mm}$ length. Posterior cardinal angle distinctly $>90^{\circ}$. Cardinal corners separated from lateral surface by short bulge-like swellings in prolongation of the more indistinct tecnomorphic bulge-like velum. Dolon extending from anterocentral region to centroventral region. Outer shell surface finely punctate.

Comparisons. According to Jaanusson (1957: 275) Oepikella bonnemai Öpik, 1937 differs from the type species only by the ornamention ("widely punctate", Öpik 1937: 87 or 23). Also for O.tvaerensis Jaanusson (1957 : 272, fig. 20a) mentioned "scattered pits", over the whole lateral surface and Thorslund (1940: 181) described the outer surface as "finely punctate". Both species are considered here as synonyms. This all the more, as Jaanusson (1957: 275) recorded both species also from a boulder of Tvären.
Oepikella tvaerensis and O. asklundi were considered already by Henningsmoen (1953b: 228) as "most probably one dimorphic species", i.e., as synonyms which was acknowledged by Jaanusson (1957: 271), and $O$. tvaerensis is a younger synonym of $O$. canaliculata (see also Schallreuter 1985: 102).

Another synonym of $O$. canaliculata is Tvaerenella stossmeisteri. The holotype of that species (Schallreuter 1985, pl. 3, figs $4 \mathrm{a}-\mathrm{b}$ ) resembles the tecnomophic valves of $O$. canaliculata figured in the same paper (Schallreuter 1985, pl. 3, figs 5a-b, pl. 8, fig. 1). The holotype is a $q$ valve with the velar frill broken away close to the domicilium but it seems that the frill has been tubulose like that of $O$. asklundi. The specimen is smaller than the largest $q$ valves of $O$. tvaerensis, but Jaanusson (1957: 273) already recognized a great size difference within the $q$ of that species (Jaanusson 1957, tab. 11 , fig. 8), i.e. from $2.34-3.99 \mathrm{~mm}$ (5 specimens). These females fall by their size "within the limits of the last but one moult stage, or into an even earlier moult stage" (Jaanusson 1957: 208) and thus, represent some sort of precocious sexual dimorphism (premature fertility). Wether or not more than one species is represented is morphologically indistinguishable. By contrast, females of Tetrada memorabilis (Neckaja, 1953), Brezelina palmata (Krause, 1889), and Ahla bocki (Öpik, 1935) are known already from the $\mathrm{A}^{-3}$ stage onward (Schallreuter 1976: 169; Tinn \& Meidla 2003, fig. 4). However, the preadult females are not fertile. The smallest specimen of O. asklundi Thorslund (1940: 182) recognized as females of $O$.tvaerensis are only $2.00 \mathrm{~mm}$ long. The holotype of Tvaerenella stossmeisteri measures $1.85 \mathrm{~mm}$ (without frill). With regard to the convexity of the domicilium (greatest convexity in the posterior ventral quarter) it very much resembles O. tvaerensis (compare Schallreuter 1985, pl. 3, figs $4 \mathrm{a}-\mathrm{b}$ and Jaanusson 1957, pl. 13, figs 11-13). Tvaerenella stossmeisteri is therefore considered here also as a synonym of the associated $O$. canaliculata (Schallreuter 1985, pl. 3, figs 4-5).

Oepikella luminosa Sarv, 1959 (Oandu to Porkuni stages, holotype from Pirgu stage; Meidla 1996: 21) is smaller (+ 1.62-2.00 mm; Sarv 1959: 17; Sidaravičienè 1992: 244) but has a longer dolon and may be distinctly reticulate (compare Jaanusson 1957, pl. 13, figs 1, 9 and Sarv 1959, pl. 2, fig. 14; see also Sidara-

Figure 1. A. Oepikella canaliculata (Krause, 1892), lectotype, juvenile left valve (MB. HS 2010-9), dorsal, lateral, and ventral views, L $1.98 \mathrm{~mm}$, Müggelheim (Berlin), Krause's glacial erratic boulder no. 670, age: Keila stage (D2); B. Oepikium antiquatum (Krause, 1889), holotype, tecnomorphic right valve (MB. HS 2010-10), frill posteroventrally broken away, lateral view, L $2.32 \mathrm{~mm}$, Rixdorf (Berlin), Krause's glacial erratic boulder no. 187, exact age unknown, presumably lower Viruan; C. Duplexibollia duplex (Krause, 1892), holotype, anteriorly incomplete left valve (MB. HS 2010-15), lateral view, L $2.75 \mathrm{~mm}$, Müggelheim (Berlin), Krause's glacial erratic boulder no. 640, age: Pirgu stage or Porkuni stage (F1c or F2); D. Signakiella signata (Krause, 1892), lectotype, right valve (MB. HS 2010-2), lateral view, L 2.54 mm, Müggelheim (Berlin), Krause's glacial erratic boulder 648, age presumably Keila stage (D2); E. Signakiella signata (Steusloff, 1895) = S. asteusloffi Schallreuter, 1988, lectotype, left valve (GG 114-59), lateral view, L $2.00 \mathrm{~mm}$, Neubrandenburg, glacial erratic boulder, age presumably Keila stage (D2); F. Uhakiella granulosa (Krause, 1889), lectotype, right male valve (MB. HS 2010-12), lateral view, L 2.08 mm; Müggelheim (Berlin), Krause's glacial erratic boulder no. 339, age Viruan; G. Vauscripta v-scripta (Krause, 1889), lectotype, right tecnomorphic valve (MB. HS 2010-5), lateral view, L $1.78 \mathrm{~mm}$; Berlin or Mark Brandenburg, Krause's glacial erratic boulder no. 112, age presumably Aseri (C1a). All stereo-pairs. 


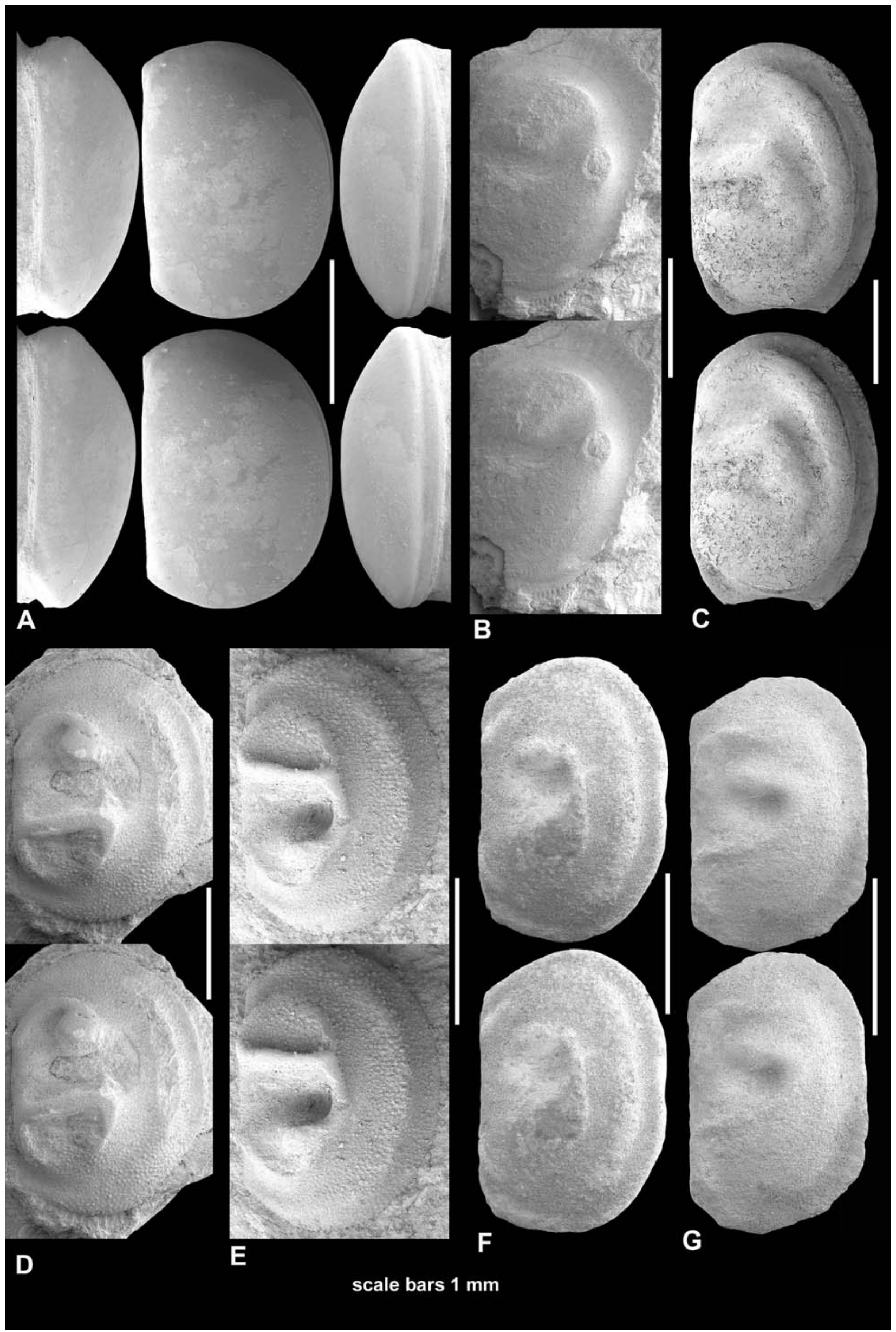


vičienè 1992, pl. 36, fig. 10). According to Sarv (1959: 17), only the anterior of the bulge-like swellings ("diagonal lobes") of the cardinal corners is developed. The posterior end of the valve is less convex.

Oepikella ? alta Schallreuter, 1984 reaches only $1.25 \mathrm{~mm}$ and has a long dolon extending from the anteroventral region to the posterocentral region (Schallreuter 1984a, fig. 1.1). Tecnomorphic valves of that species are unknown (designation therefore only with "?").

Remarks. Since $O$. canaliculata is the most common ostracode species in the glacial erratic boulder (age: D2) described by Krause (1892: 385), Andersson (1893: 125) called this association "Isochilina canaliculataFauna" and considered it (Andersson 1893: 219) as an equivalent of the Chasmops macrourus zone (Keila stage, ? Oandu stage) of Öland. In the boulders of the Tvären area (age: Kukruse to Jõhvi stages, C2-D1, Schallreuter 1970: 301) O. canaliculata is “... one of the commonest species" (Jaanusson 1957: 275).

Occurrence. Glacial erratic boulder of Keila stage (age: D2): Krause's glacial erratic boulder no. 670 (Harpa Limestone); glacial erratic boulder no. STEU-4a (Macrourus Limestone; Steusloff 1895: 779), glacial erratic boulder Ahl-1001 (Harpa Limestone, Schallreuter 1985: 102). Estonia: Uhaku and Kukruse stages $(\mathrm{C} 1 \mathrm{c}-\mathrm{C} 2 \alpha)$, Sweden (Tvären): boulders of lowermost Ludibundus limestone (Kukruse stage; Jaanusson 1960, tab. 1).

Family Oepikiidae Jaanusson, 1957

\section{Oepikium Agnew, 1942}

Synonym. Biflabellum Öpik, 1935 non Döderlein, 1913.

Type species. Biflabellum tenerum Öpik, 1935; by original designation.

Definition. Schallreuter 1975: 175.

\section{Oepikium antiquatum (Krause, 1889)}

\section{Figure 1B}

1889 Entomis sigma var. - Krause: 13, 23, pl. 1, fig. 13.

1891 Entomis sigma v. antiquata Krause: 509, 518.

1934 Ctenobolbina antiquata. - Bassler \& Kellett: 55, 254, 306.

? 1992 Oepikium sp. - Sidaravičienè: 151, 244, tab. 2, pl. 38, fig. 2.

? 1993 Vittella ? aff. antiquata. - Schallreuter: 36, 244, pl. 48b, fig. 1.

Holotype (monotypy). Right valve, frill posteroventrally incomplete, MB. HS 2010-10, Figure 1B, Krause 1889, pl. 1, fig. 13.

Type locality and horizon. Rixdorf, Mark Brandenburg (now part of Berlin); Krause's glacial erratic boulder no. 187, a greenish-grey marly limestone with Primitia bursa Krause, 1889, Entomis sigma Krause, 1889, Ampyx sp. and Cheirurus sp., age presumably Middle Ordovician.

Dimensions. Holotype: L with frill anteriorly but without posterior spines $2.32 \mathrm{~mm}, \mathrm{H}$ with frill $1.45 \mathrm{~mm}$.

Definition. At least up to $2.32 \mathrm{~mm}$. Long sigmoidal S2, being deep also in its ventral part, lobes strongest in ventral part, top of poster- oventral lobe node- or spine-like, ventral ends of lobes connected by an indistinct ridge.

Remarks. The top of the posteroventral lobe is broken away so that it is unclear whether it terminates in a node or spine (Stachel =lobal spine). Velar flange broad and plane, radially striated and with very fine ridges parallel to the border.

Comparisons. O. antiquatum differs from all other Baltoscandian species of the genus [O. flabelliferum (Krause, $1892)=$ Biflabellum reticulatum Öpik, $1937=$ B. crista Öpik, 1937; O. tenerum (Öpik, 1935), O. porkuniensis Henningsmoen, 1954, O. novum Sarv, 1959] mainly by the more distinct $\mathrm{S} 2$ and the ventrally stronger developed lobes (Öpik 1937, pl. 5, figs 1-8; Schallreuter 1975, pl. 8, figs 2-3; Schallreuter 1993, pl. 61b, fig. 4; Schallreuter \& Hinz-Schallreuter 2007, fig. 4).

Oepikium sp. A Jaanusson, 1957 from the South Bothnian glacial erratic boulder Erken no. 10 (Crassicauda limestone $=$ Uhaku stage, $\mathrm{C} 1 \mathrm{c})$ has a similar S2 but differs also by the ventrally weaker lobes (Jaanusson 1957, pl. 14, fig. 5). The specimen figured by Jaanusson is smaller (L $1.79 \mathrm{~mm}$ ) and probably a female. The sausage-shaped elevation of the frill (Jaanusson 1957: 408) seems to be an antrum restricted to the inner part of the frill because it has the width of the presumed diameter of the eggs stored in similar constructions of other species and genera (O. tenerum, Öpik 1937, pl. 5, fig. 2; Tallinnellina divelata, Sarv 1963, pl. 2, figs 4-5; Snaidar radians, Schallreuter 1976, pl. 8, figs 4-5; Femerensia gealbertii, Schallreuter 1983c, pl. 94, fig. 2).

Occurrence. Despite its large size (L $2.32 \mathrm{~mm}$ ) the species has not been found in Baltoscandian outcrops. Sidaravičienè (1992, pl. 38, fig. 2) figured an incomplete and compressed specimen of Oepikium from the Lasnamägi stage $(\mathrm{Clb})$ of Lithuania (L $1.65 \mathrm{~mm}$ without velar frill), which may be conspecific to O. antiquatum.

The incomplete left valve figured by Schallreuter (1993, pl. 48b, fig. 1; L $2.34 \mathrm{~mm}$ ) may also belong to that species. Unfortunately the portion ventral to the center of S2 is broken away. The boulder has been referred to the middle and upper Kunda stage $(\mathrm{B} 3 \beta-\gamma)$.

Superfamily Hollinoidea Swartz, 1936

Family Tvaerenellidae Jaanusson, 1957

Subfamily Tvaerenellinae Jaanusson, 1957

\section{Uhakiella Öpik, 1937}

Type species. Uhakiella coelodesma Öpik, 1937; by original designation.

Remarks. Henningsmoen (1953b: 226) considered Uhakiella as a younger synonym of Primitia Jones \& Holl, 1865 with Beyrichia strangulata as type species. Jaanusson also studied the type material of Beyrichia strangulata and according to his observations there hardly remains any doubt of this species belonging to 
Uhakiella (Jaanusson 1957: 288). Although Miller (1889: 561) had already cited Beyrichia strangulata McCoy, 1951 as type species for Primitia his designation was long time neglected in favour of Beyrichia mundula Jones, 1855 as the respective type species (U1rich \& Bassler 1923: 300; Bassler \& Kellett 1934: 438; Swartz 1936: 549) until Henningsmoen (1953b: 225) argued against this wrong use and re-established Beyrichia strangulata. Because of the great nomenclatorical consequences an application to the International Commission on Zoological Nomenclature was submitted to suppress Miller's designation of Beyrichia strangulata in order to maintain the accustomed usage of Primitia mundula as type species of Primitia (Jaanusson 1957: 217, 288). However, Primitia is still a bag genus for unisulcate species of uncertain relationships and best considered as a nomen dubium.

Schmidt (1941: 33, 96, pl. 5, figs 43a-d) considered Uhakiella Öpik, 1937 to be synonymous with the North American genus Bromidella. The latter was erected by Harris in 1931 in a paper not cited by Öpik. Thorslund (1948: 344, 350, 359) and Henningsmoen (1948: 416) agreed with this opinion. However, after having re-examined the type material of Beyrichia strangulata Henningsmoen (1953b: 226) found that the strong dorsal ridge of Bromidella is rather unique so that Henningsmoen "concluded that it may be better to retain Bromidella as a separate genus" (Jaanusson 1957: 288).

The type-species of Bromidella differs from Uhakiel$l a$, not only by the very strong dorsal plica but also by the missing ventral bulge and the development of the tecnomorphic velum as a row of spines which is most distinct on the posterior part of the brood pouch (Williams \& Siveter 1989, pls 4, 16, figs 1-4).

The Baltoscandian Bromidella sarvi Schallreuter, 1964, which occurs together with Uhakiella, not only has a strong dorsal plica but also a distinct ventral bulge like Uhakiella. On the other hand, juveniles of $B$. sarvi have their tecnomorphic velum developed as a narrow flange and in the posterior part also as a row of spines (Schallreuter 1973, pl. 20, figs 4-5; 1983b, pl. 10, 28, figs 1-2).

Despite the differences between Bromidella and Uhakiella some Baltoscandian authors have not agreed with the assignment of B. sarvi and related species to Bromidella and still consider them as species of Uhakiella (Gailīte 1973; Jaanusson 1976; Sidaravičienè 1992). Nevertheless, Sidaravičienè (1996: 55, fig. 13) noted that these species represent at least a separate branch within Uhakiella. Therefore, we consider it as a possible new genus or subgenus of Uhakiella.

\section{Uhakiella granulosa (Krause, 1889)}

Figure $1 \mathrm{~F}$

1889 Bollia granulosa Krause: 14-15, 22-24, pl. 2, figs 1-2.

1908 Beyrichia granulifera Ulrich \& Bassler: 285, 294, 328, fig. 32, pl. 38, fig. 7 (after Krause 1889, pl. 2, fig. 2). non 1909 Bollia granulosa. - Bonnema: 63-65, 78, 84, pl. 4, figs 12-18 (= Uhakiella kohtlensis Öpik, 1937: 108 or 44).

1933 Ctenobolbina granulosa. - Kummerow: 48-49.

1937 Uhakiella granulosa $=U$. granulifera. - Öpik: 4, 42-43, 68, 106-107.

1941 Bromidella granulosa. - Schmidt: 33, 80.

1954b Primitia granulosa. - Heningsmoen: 75.

1988b Uhakiella granulosa. - Schallreuter: 41, fig. 2.2.

1992 Uhakiella granulosa. - Sidaravičienè: 87-88, 237-238, tab. 2, pl. 22, fig. 10 , pl. 23, figs $1-2$.

1996 Uhakiella granulosa. - Sidaravičienè: 13, 16, 51, figs 2-3, 5-

11, 13 (faunal $\log$ ); tabs 2-5.

Lectotype (designated by Öpik 1937: 106 or 42). Right ô valve, MB. HS 2010-12 - Figure 1F, Krause 1889, pl. 2, fig. 2; Ulrich \& Bassler 1908, fig. 32, pl. 38, fig. 7; Schallreuter 1988b, fig. 2.2 .

Type locality and horizon. Müggelheim (Berlin), Krause's glacial erratic boulder no. 339, age Viruan.

Dimensions (L - H in mm - L : H). Lectotype $2.08-$ 1.30 - 1.60. Sidaravičiené 1992, pl. 22, fig. 10 (left + valve, C3) $2.65-1.75-1.51$, pl. 23, fig. 1 (left $q$ valve, C2) $2.55-1.65-1.55$, pl. 23, fig. 2 (left ô valve, C3) $2.45-1.60-1.53$.

Definition. Adults $2.08-2.65 \mathrm{~mm}$. S2 as a distinct relatively broad pit, PAN weak, \pm distinct zygal crista, dorsal plica and ventral bulge, tecnomorphic velum as an indistinct narrow bulge, in ô centroventrally reduced, $q$ with closed false brood pouch in the anteroventral region. Surface of domicilium and antrum with closely set spines.

Comparisons. U. granulosa resembles very much U. coelodesma which differs mainly by the weaker plica (compare Figure 1F and Öpik 1937, pl. 3, figs 1, 3; Sarv 1959, pl. 4, figs 6-7; Sztejn 1985, pl. 1, fig. 5; and Sidaravičiene 1992, pl. 22, fig. 10, pl. 23 figs 1-2).

In U.jaanussoni (especially in the nominate subspecies) the ornamental features are even weaker than in $U$. granulosa, so that there is no furrow between the lateral surfaces of domicilium and brood pouch (Schallreuter 1973, pl. 19, fig. 3; Sidaravičienè 1992, pl. 23, fig. 3). In the younger (Skagen, Keila stage) U.jaanussoni skageni ornamentation is more distinct.

A common feature of U. granulosa, U. coelodesma, and $U$.jaanussoni is the centroventral incisure of the $\delta$ velum (Öpik 1937, pl. 3, fig. 1; Sarv 1959, pl. 4, fig. 7; Sidaravičienė 1992, pl. 23, fig. 2; Schallreuter 1973, pl. 19, figs 1, 8). This feature has been observed in these three species only. Therefore, they may represent only one species with several subspecies (cf. Schallreuter 1973: 79) because transitions exist in other features. However, Jaanusson (1963: 25, 28) who studied the type of U. granulosa (Jaanusson 1962: 412; 1963: 5), considered U. granulosa and U. coelodesma as different species, and also Sidaravičiene 1992 cited U. coelodes$m a$, U. granulosa and U. jaanussoni as different species of a phylogenetic lineage within Uhakiella (Sidaravičienè 1996: 55, fig. 13).

With up to $2.75 \mathrm{~mm}$ Uhakiella jonesiana (Schmidt, 1941) (= Primitia jonesii Krause, $1889=$ U. magnifica Sarv,1959; Schallreuter 1973: 78) becomes larger (Sidaravičiene 1992: 238) and differs also by the narrower $\mathrm{S} 2$, the stronger plica, and the weaker ventral bulge, which is documented only by an accumulation of tuber- 
cles. Furthermore, the pouch exhibits a finer granulation than the lateral surface of the domicilium (Sarv 1959, pl. 3, fig. 10, pl. 4, fig. 16; Sidaravičienè 1992, pl. 24, fig. 3; Meidla 1996, pl. 4, figs 10-11). Whether or not the male velum has a ventral incisure is unknown.

Uhakiella labrosa (Krause, 1889) (= U. aequigranosa Jaanusson, 1957, uppermost Crassicauda limestone) is of about the same size (holotype of $U$. aequigranosa $2.10 \mathrm{~mm}$ ) and differs from U. granulosa and other species of the genus by its ornamentation and the indistinct ornamental ridges (Jaanusson 1957: 291, pl. 5, fig. 10). Males seem to be unknown so that it is also not known whether a ventral incisure exists or not.

In Uhakiella oanduensis Sarv, 1963 the ventral incisure is apparently lacking. The plica is more distinct and the surface ornamentation consists of granules and few tubercles instead of spines (Meidla 1996, pl. 4, figs $12-13)$.

Remarks. For Bollia granulosa Ulrich \& Bassler (1908: 294, 328) introduced the replacement name Beyrichia granulifera after assigning this species to the genus Beyrichia (secondary homonymy). Already Bonnema (1909: 84 ) considered the shifting of Bollia granulosa into Beyrichia only weakly founded, but it became irrelevant (Schmidt 1941: 33 footnote) when Öpik, on one hand and Schmidt, on the other hand, assigned this species to Uhakiella (Öpik 1937: 42-43, 106-107) or Bromidella, respectively (Schmidt 1941: 33).

In unawareness of this remark, the name granulifera has been further used, but mostly only in lists in the sense of ICZN art. 23.9.6. In the few papers contributing to the knowledge of the taxon the name granulosa has been prefered. This also applies to the present paper (in the sense of ICZN art. 59.29) despite the existence of a replacement name since its irrelevancy has been recognized already in 1941 .

Kummerow (1933: 48-49, fig. 8) mentioned the external sausage-like brood pouch ("false" brood pouch) in Eurychilina kuckersiana and Ctenobolbina (= Bollia) granulosa from weathered Backsteinkalk glacial erratic boulders and figured a steinkern of Eurychilina kuckersiana, which Öpik (1937: 43) considered as Uhakiella sp.

Kummerow (1939: 89) disagreed and stated that both species occur together in the Backsteinkalk. For comparative reasons he reproduced his figure 8 (1939 as fig. 9) and refigured copies of both species from Bonnema (1909, pl. 7, figs 13-14).

However, the copy of Bollia granulosa in fact represents Bromidella kohtlensis Öpik, 1937 (= Bollia granulosa: Bonnema, 1909) with a distinct false brood pouch like U. granulosa.

The refigured E. kuckersiana on the other hand represents in reality Severobolbina kuckersiana, which lacks a false brood pouch contrary to U. granulosa but displays quite another kind of dimorphism. However, it seems that Kummerow erraneously figured (same spe- cies name!) the wrong figure of Bonnema. He probably meant Laccochilina kuckersiana which has a false brood pouch like $U$. granulosa. In accordance with this assumption Sarv (1959: 9) cited Eurychilina kuckersiana Kummerow, 1933 under Laccochilina kuckersiana.

Later investigations of Backsteinkalk ostracodes by the senior author evidenced, that Kummerow's Ctenobolbina granulosa is identical with Bromidella sarvi (Schallreuter 1973: 86). The latter is very similar to Bromidella kohtlensis according to the figure of that species reproduced by Kummerow. According to his short description (Kummerow 1939: 89) his Eurychilina kuckersiana seems to be identical with Uhakiella jaanussoni Schallreuter, 1964. Posthumously, one must agree Öpik (1937: 68) in placing Eurychilina kuckersiana sensu Kummerow $(1933,1939)$ in Uhakiella.

Occurrence. Lithuania: Sidaravičiene 1996 mentioned $U$. granulosa and U. coelodesma both from the Lasnamägi stage and Uhaku stage, U. granulosa also up to undivided Idavere/Johvi (= Haljala stage) but not from Jõhvi stage. In her figure 13 (stratigraphical and phylogenetical ranges) $U$. coelodesma is restricted to Lasnamägi stage and Uhaku stage, U. granulosa to the Kukruse stage and lower Idavere substage. Western Latvia: Kukruse and Haljala stages, eastern Latvia: Kukruse stage.

\section{Signakiella Schallreuter, 1988}

Type species. Strepula signata Steusloff, 1895 (= Signakiella steusloffi Schallreuter, 1988b); by original designation.=Beyrichia signata Krause, 1892 = Steusloffia wandae Sztejn, $1989=$ Piretella $?$ paezerensis Sidaravičienè, 1992.

Definition. Large, amplete or slightly preplete, unisulcate, S2 as a distinct pit behind of a small but distinct PAN. Strong zygal ridge starting from PAN and continuing around S2 and as C3 until the dorsal plica. In front of the PAN the latter is followed by an anterior ridge (C1), which terminates ventrally at the zygal ridge. Posteroventrally of $\mathrm{S} 2$ at the zygal ridge $\mathrm{C} 4$ starts as a short ridge.

Comparisons. Signakiella is closely related to Uhakiella and very probably a descendent of the latter. Most important common features are the pit-like S2, PAN, dorsal plica, zygal ridge, and ventral bulge ("ventral lobe" of Öpik 1937, fig. 5). Signakiella differs from Uhakiella mainly by the much stronger rich-like ornamental sculptures, particularly by the much stronger ventral bulge and the development of a parable-like ridge around PAN and S2, which incorporates the zygal ridge.

There are several homeomorphic genera with a parable-like ridge $(\mathrm{C} 1+\mathrm{C} 3)$ around both PAN and $\mathrm{S} 2$ such as Piretella, Vauscripta (= Mojczella), Pectidolon, Asteusloffia, and Steusloffia, in which the species partly had been placed. From these genera Signakiella differs mainly by the ventral bulge.

Signakiella also resembles Lennukella Jaanusson, 1957 mainly in the dorsal plica, the PAN and the ventral bulge, but differs by the development of a short ridge, a node below and above the middle of the post- 
sulcal area as well as of a narrow velar flange (Öpik 1937, pl. 3, figs 11-12; Jaanusson 1957, fig. 34, pl. 10, fig. 1)

\section{Signakiella signata (Krause, 1892)}

Figure 1D-E

1892 Beyrichia (Tetradella) signata Krause: 395, 399, pl. 21, fig. 4. 1895 Strepula signata Steusloff: 784-785, pl. 58, fig. 25.

1908 Beyrichia (Steusloffia) signata. - Ulrich \& Bassler: 295, 296.

1934 Steusloffia signata. - Bassler \& Kellett: 55, 206, 476-477, 483. 1973 Uhakiella signata. - Schallreuter: 78.

1988b Signakiella asteusloffi Schallreuter: 40-41, fig. 2.1.

1989 Steusloffia wandae Sztejn: 4, 8-9, 18-19, 20, 22, 72, 76-77, $86-88,90$, tab. 1 , pl. 2 , fig. $1 \mathrm{a}-\mathrm{d}$.

1992 Piretella ? paežerensis Sidaravičienè: 145, 146, 244, tab. 2, pl. 37, figs 4-9.

1993 Signakiella cf. asteusloffi. - Schallreuter: 16, 72, 252, tab. 2, pl. 52 b, fig. 4 .

1995 Signakiella steusloffi. - Schallreuter: 127-128, tab. 2, fig. 1

1996 Piretella ? paežerensis. - Sidaravičienè: 16, 51, 56, tabs 4, 6, figs 3-4 (faunal $\operatorname{logs}$ ).

Lectotype (designated here). Right valve, MB. HS 2010-2, Fig. 1D; Krause 1892, pl. 21, fig. 4.

Type locality and horizon. Müggelheim (Berlin), Krause's glacial erratic boulder no. 648, a "graues, ziemlich festes, splittriges Geschiebe", presumably Keila Stage (D2).

Lectotype of Strepula signata. Left valve, GG-114-59 - Figure 1E; Steusloff 1895 , pl. 58, fig. 25, Neubrandenburg, presumably Keila Stage (D2).

Material. From the several specimens of Krause (1892: 395) only the figured one had been at the authors disposal. From Steusloff's Strepula signata two left valves (lectotype and paratype) and an external mould of a left valve (Schallreuter 1988, fig. 2.1) had been available.

Dimensions and proportions ( $\mathrm{L}-\mathrm{H}$ in $\mathrm{mm}-\mathrm{L}: \mathrm{H})$. Lectotype: $2.54-1.77-1.44$. Lectotype of Strepula signata $2.00-1.37-1.46$. Holotype of Piretella? paczerensis: 3.25 - $2.00-1.63$, specimen no. 13-249/ 2 of Sidaravičienè 1992, pl. 37, figs 6-7: $2.50-1.75-$ 1.43. S. wandae (after Sztejn 1989: 76) holotype $2.63-$ 1.83 - 1.44, paratype 8348/88/O $2.94-1.53-1.92$ (measurements incorrect?, after figure pl. 2, fig. 1d and magnification L only $1.78 \mathrm{~mm}$ ). Specimen of Schallreuter: 1995 , fig. $1: 3.58-2.30-1.56$.

Definition. As for the presently monotypic genus.

Remarks. Younger synonyms are Strepula signata Steusloff, 1895, Signakiella asteusloffi Schallreuter, 1988, Steusloffia wandae Sztejn, 1989 and Signakiella paczerensis (Sidaravičienè, 1992). Already Bassler \& Kellett (1934: 476) considered Strepula signata Steusloff and Beyrichia signata Krause as synonyms.

Dimorphism. Until now, none of the available specimens shows dimorphic features. However, the largest known specimen does not exceed $3.58 \mathrm{~mm}$ (Schallreuter 1988b: 128) and the yet presented material is even smaller. Therefore, adult females seem to be absent rather than that dimorphic features are not developed. This all the more, as Signakiella is closely related to Uhakiella and thus, dimorphism with a strongly convex dolon ("false" brood pouch) in the anteroventral region is to be expected.

Occurrence. Lithuania: Haljala Stage (C3/D1); mideastern Poland: Kukruse - Keila; ? Östergotland. Glacial erratic boulders (D2 and perhaps older) of northern Germany.

\section{Vauscripta Schallreuter, 1988}

Synonym. Mojczella Olempska, 1989

Type species. Bollia v-scripta Krause, 1889; by original designation. Type species of Mojczella: M. jaanussoni Olempska, 1989; by original designation.

Definition. Medium-sized - large, S2 pit-like, distinct oval PAN, zygal ridge and $\mathrm{C} 3$ forming a v-shaped ridge, $\mathrm{C} 1$ isolated or connected anteroventrally with $\mathrm{C} 3$. $\mathrm{C} 1$ and $\mathrm{C} 3$ passing dorsally into the two branches of the plica. Velum anteriorly and ventrally as a ridge or more or less broad flange which may be undulate, in females weakly or strongly convex. Outer surface reticulate and tuberculate or smooth.

Dimorphism. The knowledge about mode and formation of the dolon/antrum in Vauscripta is rather limited since females are extremely rare. Olempska (1989a, pl. 17, figs 5-6; 1989b: 162) mentioned and figured few females with a slightly convex undulate dolon but mentioned also a fragmentary heteromorph with a strongly convex dolon. The female figured by Sidaravičienè (1992, pl. 36, fig. 12) seems to have such a strongly convex dolon forming a long false brood pouch. This specimen is rather large with $2.15 \mathrm{~mm}$, and tecnomorphs may even reach $2.40 \mathrm{~mm}$. This shows that the majority of the material described is juvenile.

Olempska (1989b: 162) mentioned a "very fine transversal striation (but without traces of fused spines)" at the heteromorphic velar flange. Such striation was also observed in tecnomorphs (Schallreuter 1993, pl. 39b, fig. 4), but mostly striation or undulation is rather indistinct for preservational reasons.

Comparisons. There are several genera characterized by a parable-like crista formed by $\mathrm{C} 1$ and $\mathrm{C} 3$ and enclosing both PAN and S2. This feature is, therefore, homeomorphic and complicates the systematic differentiation between Vauscripta and Mojczella as well as between Uhakiella and Signakiella (Tvaerenellidae), Piretella and Lembitsarvella (Piretellidae), Asteusloffia (Ctenentominae, Ctenonotellidae), and Pectidolon (Wehrliinae, Ctenonotellidae).

Before becoming the type-species of Vauscripta, Bollia v-scripta was assigned to Uhakiella, Tvaerenellidae (Öpik 1937; Schallreuter 1973). Olempska also referred Mojczella to the Tvaerenellidae, while Sidaravičienè (1992: 145, 147) assigned it to the Piretellinae. The taxonomic problems are also exemplified by species originally erected within the genus Piretella: Vauscripta tridactyla (Jaanusson, 1957),

Features such as the pit-like S2, the PAN, the zygal ridge, and the plica indicate close relationships between 
Vauscripta, Uhakiella and Signakiella. Main differences between the three genera refer to the ventral bulge present in Uhakiella and Signakiella and the C3 and velar flange developed in Vauscripta. In lobation and cristation transitions exist between Uhakiella and Vauscripta as shown, e.g., by the two valves figured by Thorslund (1940, pl. 1, figs 6-7) as Uhakiella coelodesma.

Differences seem to exist in the construction of the tecnomorphic velum and perhaps the dimorphism. In Uhakiella the tecnomorphic velum is reduced to a narrow broad bulge and in typical species with a centroventral incisure in the males. By contrast, Vauscripta has a relatively broad velar flange which forms a weakly convex undulate dolon or strongly convex pouch in females.

More than typical Uhakiella species does Vauscripta very much resemble the Baltic species assigned to Bromidella in their ridge- or flange-like tecnomorphic (part of) velum. It is very likely that Vauscripta (Schallreuter 1988b: 42; 1993, pl. 50a, figs 2-3, pl. 52b, figs 1-3) originated from this Bromidella branch.

Vauscripta also resembles the two ctenentominine genera Asteusloffia and Ctenentoma. Vauscripta and Asteusloffia are very similar in the construction of the plica (compare Fig. 3C and Olempska 1989a, pl. 18, fig. 6) but in Asteusloffia the distance between PAN and $\mathrm{C} 1 / 3$ is larger and a connection between them is lacking. Furthermore, Asteusloffia exhibits a C4.

In the formation of an undulate velar flange as well as in the kind of dimorphism (weakly convex dolon) Vauscripta resembles very much Ctenentoma (Schallreuter 1994, pl. 17, fig. 3). Similarity exists also concerning S2, PAN and postsulcal ridge. Vauscripta has only more ridges on the lateral surface.

Comparable features to Steusloffia refer to S2, PAN, cristae and sometimes an undulate velar flange (Schallreuter 1993, pl. 39b, figs 3-4).

In the development of $\mathrm{C} 1 / 3$ Mojczella very much resemble Signakiella also showing the slight bending at the connection point beneath the PAN (Olempska 1989b: 164) (compare Fig. 1G and Olempska 1989a, pl. 19 , figs $3-4,8$ - for the first time already at least in the samples MA-58 and MA-59, not MA-65 and MA-66).

Signakiella differs mainly by the ventral bulge, the short $\mathrm{C} 4$, and the missing velar flange. This fact clearly demonstrates the striking homeomorphic nature of the $\mathrm{C} 1 / 3$ character.

Piretella to which one synonym of the type-species was originally assigned has an uninterrupted $\mathrm{C} 1 / 3$ like adults of the type-species and M. sanctacrucensis (Olempska 1989a, pl. 19, figs 7-8; Sidaravičienè 1992, pl. 37, figs 1-2). The velum of Piretella consists of a frill with hollow tubules and long spines in both centroventral and posterior region of the valve. Spines may occur also in the posterior region of Vauscripta, but they are only short and restricted to that area because of the longer velar flange. The distance between $\mathrm{C} 1 / 3$ and the velum is shorter in Piretella (e.g. Sidaravičienè
1992, pl. 36, fig. 11, and pl. 37, figs 1-2). Piretella has a reticulate shell, while Vauscripta may have only a reticulogranulate outer surface (Olempska 1989a, pl. 18, figs 3-6). It is, however, mostly more or less granulate to smooth. Young Piretella instars may have C1 and C3 separated anteroventrally (Schallreuter 1975, pl. 5, fig. 2) like in the oldest species assigned to Mojczella and in larvae of M. jaanussoni (Olempska 1989a, pl. 17, figs $1-7$, pl. 18, figs $1,4-5$ ).

Phylogeny. Olempska reconstructed an evolutionary lineage of Mojczella from the Ordovician Mójcza Limestone of the Holy Cross Mountains. The lineage consists of the three chronospecies (M. polonica, $M$. jaanussoni, M. sanctacrucensis) distinguished on the basis of morphologic differences and stratigraphical occurrence. They have been "... defined in such way that the two most significant gaps in the record separate them ... and it is clear that this way of discrimination of species is actually quite arbitral" (Olempska 1989b: 167).

M. jaanussoni has been defined by $\mathrm{C} 1$ "... ending below PAN", and M. sanctacrucensis by "... C1 and C3 united beneath PAN". The largest figured valve of M. jaanussoni, a female valve (Olempska 1989a, pl. 19, fig. 4; L $2.03 \mathrm{~mm}$ ), which is older than the smaller holotype of that species, shows already a connected $\mathrm{C} 1 / 3$ like in the younger but smaller tecnomorphic holotype of M. sanctacrucensis (Olempska 1989a, pl. 19, fig. 8; L $1.80 \mathrm{~mm}$ ) which is not adult. Sidaravičienè (1992, pl. 37, fig. 1) figured a female (?) valve of $2.40 \mathrm{~mm}$ length. The unification of $\mathrm{C} 1$ and $\mathrm{C} 3$ is therefore apparantly a matter of palingenesis.

Remarks. Beside of V.v-scripta $(=V$. tridacty$l a=V$.jaanussoni), V. polonica, and V. sanctacrucensis, Piretella pontis Schallreuter \& Krůta, 1984 and Rigidella dubia Olemspka, 1994 may belong in Vauscripta.

\section{Vauscripta v-scripta (Krause, 1889)}

Figure $1 \mathrm{G}$

1889 Bollia v-scripta Krause: 13-14, 23, 24, pl. 1, fig. 18 (non fig. 17).

1896 Bollia V-scripta. - Koken: 39, 383, fig. 26d (after Krause 1889, pl. 1, fig. 18).

1908 Beyrichia v-scripta. - Ulrich \& Bassler: 299, fig. 48 (= Krause 1889 , pl. 1, fig. 18), pl. 38 , fig. 8 .

1934 Zygobolba v-scripta. - Bassler \& Kellett: 55, 221, 498.

1937 Uhakiella ? V-scripta. - Öpik: 42, 106.

1957 Piretella tridactyla Jaanusson: 279, 280-281, tab. 40, pl. 5, figs $1-5$.

1960 Piretella tridactyla. - Jaanusson: 238, 270, figs 6, 23 (faunal logs), tab. 5.

1973 Uhakiella v-scripta. - Schallreuter: 78.

1976 Piretella tridactyla. - Sidaravičienè: 52, tabs 1-2.

1982 Piretella tridactyla. - Gailīte in Ul'st et al.: 117, 127-128, 179-180, 183, figs 23 (cf.), 28 (faunal logs), tabs 8-11.

1984 Piretella tridactyla. - Laškov et al.: 82.

1985 Piretella tridactyla. - Sztejn: 61 (partim); non 61 (partim), 86, tab. 1, pl. 1, figs $2 \mathrm{a}-\mathrm{b}=$ Mojczella sanctacrucensis, Sidaravičienè 1992: 147. 
1988b Vauscripta v-scripta. - Schallreuter: 40-42, figs 2.3-4.

1989a Mojczella jaanussoni Olempska: 135, 138, 140-141, 143-144,

pl. 17 , figs $7-8$, pl. 18 , figs $1-7$, pl. 19 , figs $1-4$.

1989a Mojczella ? tridactyla. - Olempska: 138-139.

1989b Mojczella jaanussoni. - Olempska: 159, figs 2-5.

1992 Mojczella tridactyla. - Sidaravičienè: 147, 244, tab. 2, pl. 36, fig. 12.

1993 Vauscripta tridactyla. - Schallreuter: 38, 226, pl. 39b, fig. 4.

1994 Mojczella jaanussoni. - Olempska: 147-148, 153-154, 175-

176 , figs 8 , 11, tab. 2, pl. 38, figs 1 , 4-10, pl. 40, figs $1-2$.

1996 Mojczella tridactyla. - Sidaravičienè: 10, 52, tab. 2, figs 7, 10 ,

12 (faunal $\operatorname{logs}$ )

Lectotype. Right valve (MB. HS 2010-5), Figure 1G; Krause 1889, pl. 1, fig. 18; Schallreuter 1988b, fig. 2.3.

Type locality and horizon. Berlin or Mark Brandenburg, Krause's glacial erratic boulder no. 112, age: presumably Aseri Stage (C1a).

Dimensions. Lectotype L $1.78 \mathrm{~mm}, \mathrm{H} 1.07 \mathrm{~mm}, \mathrm{Hm}$ $1.10 \mathrm{~mm} ; \mathrm{L}: \mathrm{H} 1.66$

Comparisons. Vauscripta v-scripta is considered here as an older synonym of Piretella tridactyla Jaanusson, 1957 which Sidaravičienė (1992: 147) had recognized as an older synonym of Mojczella jaanussoni Olempska, 1989.

Olempska (1989a: 138) placed Piretella tridactyla only tentatively in Mojczella because its entire velum is longer than in the latter genus. This seems to apply also to Jaanusson's (1957) specimen figured on plate 5, figure 1, but not to the holotype of Piretella tridactyla. The latter agrees with jaanussoni (Jaanusson 1957, pl. 5, fig. 2) in having posteriorly a row of tubercles including the characteristical posterodorsal spine (Olempska 1989b: 162) like Mojczella. With a domiciliary length of about $1.40 \mathrm{~mm}$ the holotype of Piretella tridactyla represents only a larval stage. The smaller female valve figured by Jaanusson (1957, pl. 5, fig. 5) represents a different species (Piretia? sp.). Sidaravičienè (1992, pl. 37, fig. 1) figured a female valve of Piretella tridactyla with L $2.15 \mathrm{~mm}$ in accordance with the largest known specimen $(2.03 \mathrm{~mm})$ of Mojczella jaanussoni.

The holotype of P. tridactyla agrees in most features with the lectotype of Vauscripta v-scripta except for the anterior branch of the plica. Dorsocentrally, the latter seems to be connected with the posterior branch (Jaanusson 1957, pl. 5, fig. 2) - like in some species of Piretella (Sarv 1959, pl. 3, figs 4, 7; Sidaravičienè 1992, pl. 36, fig. 11). This feature may be a matter of variation or perhaps of subspecific importance - like in Asteusloffia acuta.

From the succession of the Mojcza limestone in the Holy Cross Mountains, Olempska (1989b, fig. 2) reconstructed a phylogenetic lineage of the Mojczella species, which is characterized by the prolongation of both $\mathrm{C} 1$ and $\mathrm{C} 3$ and their unification in the youngest species. Based on these specific features Vauscripta vscripta, Piretella tridactyla, and Mojczella jaanussoni must be considered as synonyms. This the more, as they come from about the same stratigraphical level (Upper Llanvirnian).
Remarks. The second specimen (MB. HS 2010-6) figured by Krause (1889, pl. 1, fig. 17) which came from another boulder (glacial erratic boulder no. 311) represents another species (Bromidella cf. kohtlensis) because the zygal crista is not connected with the posterior plical bow.

Occurrence. Öland: Segerstad Lst. (Platyurus Lst., Aseri Stage) (Jaanusson 1960); Latvia: Upper Ziemel'skaja (C1a) (Gailite in Ulst et al. 1982); Lithuania: $M$. tridactyla Zone, Rokišksis Fm., Aseri Stage (Laškov et al. 1984; Sidaravičienė 1976, 1992, 1996); Holy Cross Mountains: Pygodus anserinus zone (Olempska 1989a, 1989b). Glacial erratic boulders: Upper Gray and Upper Red Orthoceras Lst. (Kummerow 1924; Schallreuter 1993).

\section{Euprimites Hessland, 1949}

Type species. Euprimites reticulogranulatus Hessland, 1949; by original designation.

\section{Euprimites intermedius (Krause, 1889)}

Figure $2 \mathrm{~F}$

1889 Primitia intermedia Krause: 11, 23, pl. 1, fig. 16.

1934 Eurychilina intermedia. - Bassler \& Kellett: 55, 315, 446.

1962 Primitia intermedia = Euprimites sp. indet. - Jaanusson: 413.

1973 Euprimites locknensis. - Schallreuter: 92-94, 96, 98, 111, tab.

13, pl. 21, figs 4-11 (syn.).

1983a Euprimites locknensis. - Schallreuter: 174 (syn.).

1984b Euprimites locknensis. - Schallreuter: 93, 95-96, tab.1, figs $1 \mathrm{a}-\mathrm{b}, 2 \mathrm{~b}$.

1992 Euprimites locknensis. - Sidaravičienè: 97-98, 239, tab. 2, pl. 25 , fig. 12 .

1993 Euprimites (Euprimites) locknensis. - Schallreuter: 44, 116117,172 , pl. 12b, fig. 3 (syn.).

1996 Euprimites locknensis. - Sidaravičienè: 13, 16, tabs 2-4, figs 3, 4 (Suprimites l.), 6-7, 10.

Lectotype (designated by Jaanusson 1962: 413). Left female valve, MB. HS 2010-7, Figure 2F; Krause 1889, pl. 1, fig. 16.

Type locality and horizon. Müggelheim; Krause's glacial erratic boulder no. 339, a grey, marly limestone, age presumably like Ludibundus limestone of Sweden.

Dimensions. L of lectotype $1.46 \mathrm{~mm}$, holotype of E. locknensis $1.46 \mathrm{~mm}$.

Definition. Females between 1.30 and $1.70 \mathrm{~mm}$ and mostly moderately high. Outline more or less amplete. Domicilium rather weakly convex. Sulcus very broad and relatively long, in its central part somewhat constricted, anteroventral depression present. Velum in tecnomorphs as flange-like keel, in females as a flange. Anterocentral part of flange extending perpendicular, centroventral part parallel to straight dorsal margin. End of dolon anteriorly indistinct, antrum not very deep, anteriorly open and posteriorly indistinctly closed. Lateral surface reticulate.

Remarks. After investigation and designation of the lectotype Jaanusson (1962: 413) considered P. intermedia as a nomen dubium. However, new SEM stereopairs clearly evidence that it is a senior synonym of E. locknensis. The broad S2 is a very characteristic feature. 


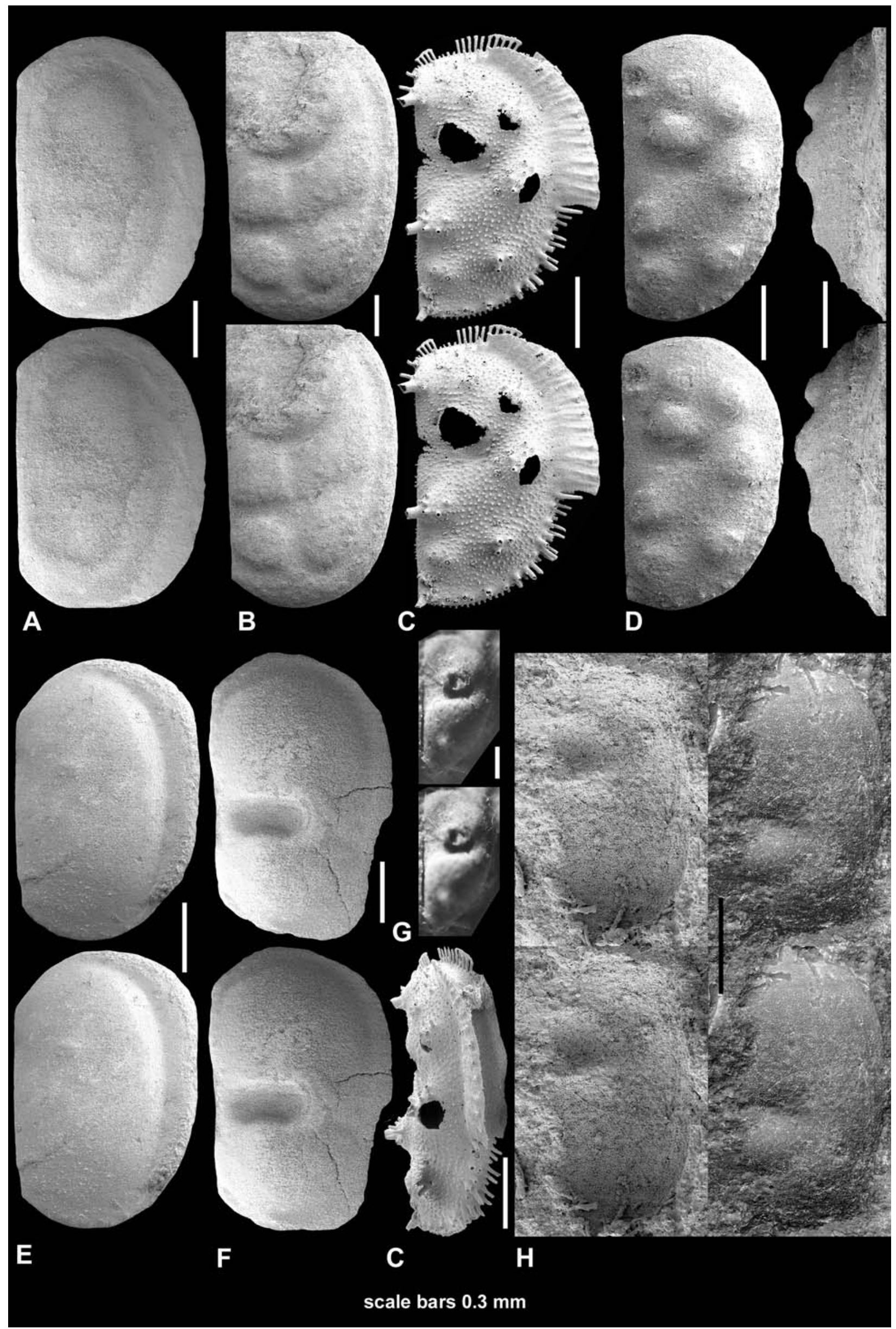


Occurrence. E. locknensis is reported from outctrops and borings of the Central Baltoscandian confacies belt (Sweden, SE Estonia, Latvia, Lithuania, Belorussia, former East Prussia) from the Aseri stage (C1a) up to the Keila stage (D2) (Schallreuter 1993: 117). From Swedish outcrops, the probable origin of the respective glacial erratic boulder, the species is recorded exclusively from the Ludibundus Limestone (= Kukruse - Haljala stages) where it is one of the commonest species (Jaanusson 1957: 310).

\section{Tvaerenella Jaanusson, 1957}

Type species. Primitiella carinata Thorslund, 1940 (OD); by original designation. = Primitia plana tuberculata Krause, $1892=$ Primitiella indistincta Öpik, 1937 = Primitiella granosa Öpik, 1937.

Definition. Schallreuter 1973: 102.

\section{Tvaerenella tuberculata (Krause, 1892)}

\section{Figure 2E}

1892 Primitia plana Krause var. tuberculata Krause: 385, 399, pl. 21, fig. 8 .

1934 Apatochilina plana tuberculata. - Bassler \& Kellett: 55, 163, 452.

1937 Primitiella indistincta Öpik: 5, 13, 60, 69, 77, 124, pl. 1, fig. 4. 1937 Primitiella granosa Öpik: 5, 14, 72, 69, 78, 136, pl. 13, figs $6-$ 9.

1940 Primitiella (?) carinata Thorslund: 163, 186, pl. 4, fig. 8.

1959 Tvaerenella granosa. - Sarv: 30-31, pl. 5, figs 4-7 (= Öpik 1937, pl. 13, figs 6-9) non figs $8-9$ (= Öpik 1937, pl. 15, figs $7-$ 8), tab. 2.

1973 Tvaerenella ? tuberculata. - Schallreuter: 102, 104.

1973 Tvaerenella granosa. - Schallreuter: 103-104, 106, 111, pl. 25, figs $1-5$ (syn.).

1983a Tvaerenella granosa. - Schallreuter: 165, 175-176, 191, tab. 16 (12/7), pl. 12, fig. 7 (syn.)

1985 Tvaerenella tuberculata. - Schallreuter: 107-108, 130, tab. 1, pl. 6, fig. 7 (syn.).

1993 Tvaerenella tuberculata. - Schallreuter: 14, 117-118, 260, pl. 56a, figs $1-3$.

Lectotype (designated by Schallreuter 1985: 107). Right $q$ valve, MB. HS 2010-8 - Figure 2E; Krause 1892, pl. 21, fig. 8.
Type locality and horizon. Müggelheim, Krause's glacial erratic boulder no. 670 .

Dimensions (L, H in mm, L : H. Lectotype $1.23-0.75$ - 1.64. Holotype of P. granosa (tecnomorphic carapace) $1.30-0.80-1.63$ (Öpik 1937), $1.20-0.88-1.36$ (Sarv 1959). Holotype of $P$. carinata (left + valve) 1.16 - 0.68 - 1.71, of P. indistincta $0.80-0.45$ - 1.77 .

Definition. Females $1.10-1.30 \mathrm{~mm}$ long and rather high to moderately high. Domicilium with indistinct sulcal depression. PAN very small and flat, situated anterodorsally of an oval, more or less distinct muscle spot with a weak interior sulcament. Tecnomorphic velum developed as keel, rounded bend or completely lacking. Dolon posteriorly extending up to the posterocentral region. Surface smooth or reticulate and more or less covered with tubercles.

Remarks. Apatochilina ubjaënsis Öpik, 1937 has been tentatively considered as a synonym of $T$. granosa (Sarv 1959: 30-31; Schallreuter 1973: 103-104) but the presence of a dorsal plica (Öpik 1937, pl. 1, fig. 10, pl. 15, figs 7-?8) clearly distinguishes this species from typical Tvaerenella species. Together with Tvaerenella caesura Schallreuter, 1993 this species possibly represents a new genus.

Occurrence. Sweden (Brunflo-Lockne area, Jämtland; Fjäcka, Siljan District): Ludibundus beds. Estonia: Uhaku and Kukruse. Glacial erratic boulders: Ringsö, Tvären; Backsteinkalk types 1B2 (Dalby), 1B3 (Skagen), 14B2 and 1B13 (Haljala Stage); Harpa Limestone (D2).

\section{Tvaerenella plana (Krause, 1889)}

Figure 2A

1889 Primitia plana Krause: 5-7, 22, 24, pl. 1, fig. 1a-b. 1896 Primitia plana. - Koken: 381, fig. 26c (after Krause).

1924 Primitiella umbilicata, Primitia u. - Kummerow: 420-421, 440, 447, pl. 20, fig. 14.

1934 Apatochilina plana. - Bassler \& Kellett: 55, 162, 452.

1954b Platybolbina plana. - Henningsmoen: 74-76, 89, 97.

1954b Öpikella cf. umbilicata. - Henningsmoen: 94-95, 101, pl. 5, figs $1-6$.

1959 Tvaerenella expedita Sarv: 34-35, 185, 195, pl. 5, figs 23-28. 1993 Euprimites ? umbilicata. - Schallreuter: tab. 3.

Figure 2. A. Tvaerenella plana (Krause, 1889), holo- or lectotype, left $q$ valve (MB. HS 2010-1), lateral view, L $1.51 \mathrm{~mm}$; Müggelheim (Berlin), Krause's glacial erratic boulder no. 310, Harjuan; B. Kiesowia dissecta (Krause, 1892), holotype, anterior incomplete right tecnomorphic valve (MB. HS 2010-3), lateral view, L $>2.05 \mathrm{~mm}$, Müggelheim (Berlin), Krause's glacial erratic boulder no. 616, age Pirgu or Porkuni stage (F1c or F2); C. Kiesowia dissecta leviconvexa (Schallreuter, 1967), holotype, right female valve (GG 25-3), lateral view, and ventrolateral views, L $1.20 \mathrm{~mm}$, Isle of Gotland, Öjlemyr flint, glacial erratic boulder (no. 794), age Pirgu or Porkuni stage (F1c or F2); D. Kiesowia dissecta (Krause, 1892), holotype of K. mamillosa (Krause, 1892), right tecnomorphic valve (MB. HS 2010-4), lateral, and ventral views, L > $2.05 \mathrm{~mm}$, Müggelheim (Berlin), Krause's geschiebe no. 667 , age Pirgu or Porkuni stage (F1c or F2); E. Tvaerenella tuberculata (Krause, 1892), lectotype, right female valve (MB. HS 20108), lateral view, L $1.23 \mathrm{~mm}$, Müggelheim (Berlin), Krause's glacial erratic boulder no. 670, age: Keila (D2); F. Euprimites intermedius (Krause, 1889), lectotype, left female valve (MB. HS 2010-7), L 1.46 mm, Müggelheim (Berlin), Krause's geschiebe no. 339, age presumably like Ludibundus limestone of Sweden; G. Balticella globifera (Krause, 1892), holotype of Balticella binodis (Krause, 1897), steinkern of a right valve (Rijksmuseum van Geologie en Mineralogie Leiden no. 34116), lateral view in two focus levels, L $1.28 \mathrm{~mm}$, glacial erratic boulder from Zwiep hill near Lochem (Staring no. 11068), age Haljala stage (C3/D1); H. Balticella globifera (Krause, 1892), dorsally incomplete external mould of lost holotype (steinkern), left valve, (MB. HS 201016), internal lateral view, and photographical cast, L $0.85 \mathrm{~mm}$, Müggelheim (Berlin), Krause's glacial erratic boulder no. 666, age presumably Haljala stage (C3/D1). All stereo-pairs except of C (ventrolateral view), and G. 
2008 Tvaerenella umbilicata. - Schallreuter \& Hinz-Schallreuter: 809-812, fig. 1.1-4. (syn.).

Holo- or lectotype. Left $q$ valve, MB. HS 2010-1 - Figure 2A, Krause 1889, pl. 1, fig. 1 .

Krause wrote that he found the species only once in a bright-grey glacial erratic boulder. It is not clear whether he meant only one specimen or several specimens in one boulder.

Type locality and horizon. Müggelheim (Berlin), Krause's glacial erratic boulder no. 310, together with Platybolbina distans. The latter seems to be a junior synonym of $P$. orbiculata, which occurs in Estonia from the Oandu (?) to Porkuni Stages (Meidla 1996: 23). Tvaerenella expedita is reported from Vormsi to Porkuni Stages of Estonia (Meidla 1996: 39), the age of the boulder is therefore, Vormsi Pirgu or Porkuni Stage.

Dimensions ( $\mathrm{L}-\mathrm{H}$ in $\mathrm{mm}-\mathrm{L}: \mathrm{H})$. Lectotype $1.51-$ $0.98-1.54$.

Definition. At least up to $1.63 \mathrm{~mm}$. Cardinal angles almost equalsized. Dolon relatively short, terminating posteriorly already in the centroventral region.

Comparisons. T. plana differs from T. tuberculata mainly by the smaller anterodorsal cardinal angle and the shorter dolon.

Remarks. P. plana is a senior synonym of Tvaerenella umbilicata and Tvaerenella expedita.

Twenty years after Bassler \& Kellett (1934) had assigned Primitia plana to the genus Apatochilina Henningsmoen (1953a) established the new genus Platybolbina for Krause's P. distans. Henningsmoen (1954b) considered Primitia plana as a possible synonym of P. distans. Reinvestigation of the type specimen of P. plana revealed, however, that it in fact belongs to the genus Tvaerenella. Accordingly, most citations in the literature concerning Platybolbina plana or Platybolbina cf. plana refer to Platybolbina distans.

In 1959 Sarv introduced the new species Platybolbina orbiculata, but Meidla (1996: 23) stated that "... until the type specimen of $P$. plana is redescribed the relationship between P. plana and P. orbiculata remains uncertain". There does not exist any relationship between Tvaerenella plana and Platybolbina orbiculata.

Occurrence. Oslo region: 4d-5b. Estonia: Vormsi Stage - Porkuni Stage. Russia (Pskov district), Latvia: Pirgu Stage. Lithuania, NW' Belorussia: Vormsi Stage - Pirgu Stage. Glacial erratic boulders: Öjlemyrflint: Isles of Gotland and of Sylt. Brandenburg: upper Ordovician limestones.
Superfamily Tetradelloidea Swartz, 1936

Family Ctenonotellidae Schmidt, 1941

Subfamily Ctenentominae Schmidt, 1941

\section{Asteusloffia Schallreuter, 1993}

Type species. Strepula lineata separata Steusloff, 1895; by original designation = Beyrichia erratica acuta Krause, 1891.

Definition. Medium-sized. Unisulcate, with distinct S2 and PAN. Dorsal plica complete or only partially developed. Three generally vertically arranged cristae: C2 missing, C1/C3 parable-like with $\mathrm{C} 4$ branching off from its posteroventral part $\mathrm{C} 4$ may or may not reach the dorsal margin.

Comparisons. From other genera with a parable-like crista around PAN and S2 (e.g., Steusloffia, Jaanusson 1957, fig. 38) Asteusloffia is distinguished mainly by the development of a C4. The similar Steusloffia in which adults and larger larvae are also characterized by a $\mathrm{C} 4$, has a $\mathrm{C} 2$ developed. Further, the $\mathrm{C} 3$ is centrally interrupted and terminates on the spine-like posteroventral lobe (Schallreuter 1993, pl. 54a, fig. 1). Although being stratigraphically older, Asteusloffia cannot be regarded as predecessor of Steusloffia because of the already lacking $\mathrm{C} 2$, which is in that lineage an advanced character.

Already Henningsmoen (1953b: 223) assumed that Steusloffia developed from forms with "normal" tetradellid arrangement of the cristae like Tallinnellina lanceolata and Rigidella mitis.

Also Steusloffia displays these four cristae, but has the $\mathrm{C} 2$ separated from the other cristae. The $\mathrm{C} 2$ is still present in the youngest species of Steusloffia, S. levis Sarv, 1959 from the Rakvere stage (E) of Estonia (Sarv 1959, pl. 15, fig. 7). By contrast, Asteusloffia acuta (= Steusloffia polynodulifera Hessland, 1949) lacks a C2 and therefore, is regarded as member of another lineage characterized by an early reduction of the $\mathrm{C} 2$.

\section{Asteusloffia lineata (Krause, 1889)}

Figure 3B

1889 Strepula lineata Krause: 15, 23, pl. 2, fig. 3 .

1934 Steusloffia lineata. - Bassler \& Kellett: 55, 475, 477.

1962 Steusloffia lineata $=$ Steusloffia $s p$. indet. - Jaanusson: 413.

Lectotype (designated by Jaanusson 1962: 413). Right valve (MB. HS 2010-11), Fig. 3B, Krause 1889, pl. 2, fig. 3.

Type locality and horizon. ? Müggelheim (not mentioned on labels), Krause's glacial erratic boulder no. 106, exact age unknown.

Figure 3. A. Asteusloffia acuta separata (Steusloff, 1895), lectotype, left valve (GG 114-51), lateral views in different positions to the SEM detector, L $0.98 \mathrm{~mm}$, Neubrandenburg, glacial erratic boulder, age B3, lower Darriwillian; B. Asteusloffia lineata (Krause, 1889), lectotype, right valve (MB. HS 2010-11), lateral, and oblique dorsal views, L $1.05 \mathrm{~mm}$, ? Müggelheim (Berlin), Krause's glacial erratic boulder no. 106, age unknown; C. Asteusloffia acuta acuta (Krause, 1891), right valve (GG 400-G123-18), lateral view, L $1.23 \mathrm{~mm}$. Black Orthoceras limestone (B3ß), local glacial erratic boulder (no. Gis-84) from Gislövshammar, Scania; D. Asteusloffia acuta acuta (Krause, 1891), left valve (GG 400-2539), lateral view, L $1.22 \mathrm{~mm}$. Same boulder as fig. 3; E. Asteusloffia acuta separata (Steusloff, 1895), paratype, external mould of right valve (GG 114-50A), internal lateral view, and photographical cast, L $1.22 \mathrm{~mm}$, same glacial erratic boulder as fig. 1; F. Bilobatia bidens (Krause, 1892), lectotype, female right valve (MB. HS 2010-14), lateral view, L 0.98 mm, Müggelheim (Berlin), Krause's glacial erratic boulder no. 670, age Keila stage (D2). All stereo-pairs. 


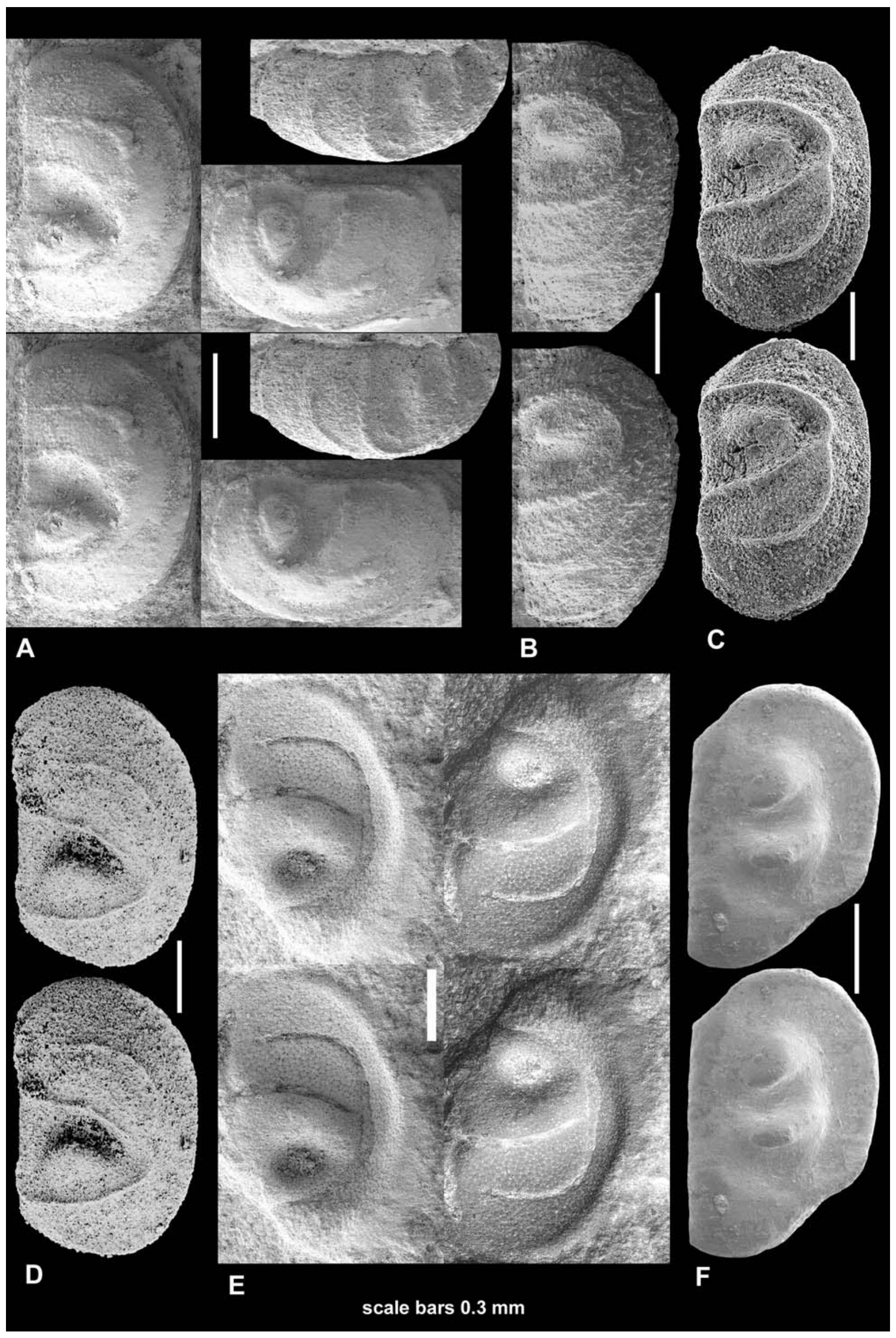


Dimensions. Lectotype L $1.05 \mathrm{~mm}, \mathrm{H} 0.61 \mathrm{~mm}$.

Definition. At least up to $1.05 \mathrm{~mm}$. Plica nearly complety missing. $\mathrm{C} 1$ and $\mathrm{C} 3$ forming a U-shaped crista around small PAN and relatively narrow S2. C4 bow-shaped, both ends directed anteriorly; dorsal end may be connected with the dorsal end of C3. Plica nearly completely missing, only represented by the short dorsal portion of C4.

Comparisons. The missing plica distinguishes $A$. lineata from all other species of the genus. Differences exist also in the cristal arrangement: $\mathrm{C} 1$ plus C3 are Ushaped in A. lineata and V-shaped in A. acuta. In A. lineata both $\mathrm{C} 3$ and $\mathrm{C} 4$ reach the dorsal margin, $\mathrm{C} 3$ extends perpendicularly to the latter. $\mathrm{C} 4$ forms a slight bow with its ends anteriorly directed; its dorsal part represents a short plica. In A. acuta, the C3 passes dorsally into the posterior part of the plica, $\mathrm{C} 4$ terminates blindly in the dorsal half of the valve (Fig. 3C-D). $A$. acuta has a larger PAN and a broader $\mathrm{S} 2$ than $A$. lineata. Consequently, C3 is located directly at the posterior border of $\mathrm{S} 2$.

A. separata (Steusloff, 1895) has been originally described as a subspecies (var.) of A. lineata. Öpik (1937: 117 or 53) considered this taxon as a species of Rigidella, Jaanusson (1957: 359) referred it to Steusloffia, and Schallreuter (1993: 68) regarded it as the type-species of Asteusloffia. However, A. separata is more similar to A. acuta (Krause, 1891). Both differ only in their plicae which is present in all parts in A. acuta separata (Fig. 3A, E; Schallreuter 1993, pl. 33b, fig. 3, pl. 34a, figs $11,21,3$, pl. 34b, fig. 4), while the centrodorsal part is lacking in A. acuta acuta (Figure 3C-D; Schallreuter 1993, pl. 31b, fig. 1r, pl. 36a, fig. 4, pl. 39a, figs 11, 2). Therefore, A. acuta separata is considered here as a subspecies of $A$. acuta, and not as a variety because of the constantness of this feature in all investigated samples.

Although the lectotype of A. lineata is smaller $(1.05 \mathrm{~mm})$ than the largest known specimens of both A. acuta separata $(1.25 \mathrm{~mm})$ and A. acuta acuta $(1.56 \mathrm{~mm})$ the lack of the plica is not an ontogenetical feature in this case. The plica is present in the species mentioned above already in specimens of about the same size (Schallreuter 1993, pl. 33b, fig. 3) or even smaller ones (Schallreuter 1993, pl. 39a, fig. 3). As demonstrated by species of the related genus Steusloffia the plica appears already in the A-3 stage with the C4 still not developed (Schallreuter 1976: 189, pl. 5, fig. 5; Hinz-Schallreuter \& Schallreuter 1998, fig. 81).

Occurrence. Known only from type locality.

Subfamily Wehrliinae Schallreuter, 1965

\section{Bilobatia Schallreuter, 1976}

Type species. Bilobatia serralobata Schallreuter, 1976; by original designation. = Beyrichia (Ulrichia?) bidens Krause, 1892.

Definition. Schallreuter 1976: 205.

\section{Bilobatia bidens (Krause, 1892)}

Figure 3F

1892 Beyrichia (Ulrichia?) bidens Krause: 396, 399, pl. 22, fig. 12. 1909 Ulrichia bidens. - Bonnema: 54, 81; non 54, 77, 81-82, pl. 6, fig. 27 = Ctenonotella elongata Öpik, 1937

1937 Ctenonotella bidens. - Öpik: 38, 102.

1959 Ctenonotella bidens. - Sarv: 72-73, tab. 2, pl. 11, figs 17-18.

1976 Bilobatia serralobata Schallreuter: 205-207, 215, tab. 12; fig. 14, pl. 8, figs 1-2 (syn.).

1982 Bilobatia serralobata. - Schallreuter: 9-15, pl. 10, figs $1-2$, pl. 12 , figs $1-3$, pl. 14 , figs $1-2$, pl. 16, figs $1-2$.

1985 Bilobatia bidens. - Schallreuter: 110-111, 120, tab. 1, pl. 1, figs 5-6 (syn.).

1990 Bilobatia bidens serralobata - Schallreuter: 255, 268, tabs 2-4, pl. 2, figs $9-10$.

1997 Bilobatia bidens serralobata - Schallreuter: figs 18a-e.

1998 Bilobatia bidens serralobata - Hinz-Schallreuter \& Schallreuter: fig. 96a-e (= Schallreuter 1997: fig. 18).

1999 Bilobatia bidens serralobata - Schallreuter et al.: pl. 1, fig. 4.

Lectotype (designated by Sarv 1959: 73, not by monotypy as mentioned by Sarv). Right $q$ valve, MB. HS 2010-14, Figure 3F, Krause 1892, pl. 22, fig. 12 .

Type locality and horizon. Müggelheim (Berlin); Krause's glacial erratic boulder no. 670 .

Dimensions. Lectotype L $0.98 \mathrm{~mm}, \mathrm{H} 0.66 \mathrm{~mm}, \mathrm{~L}: \mathrm{H}$ 1.48 .

Definition. As for the genus which is presently monotypic.

Remarks. In the population of the glacial erratic boulder Sy-108 described by Schallreuter (1982) yielded females that are much smaller $(0.90-0.96 \mathrm{~mm})$ than the holotype of the nominal type-species $B$. serralobata $(1.25 \mathrm{~mm})$. They were therefore considered (Schallreuter 1982: 13) as a possibly smaller subspecies, which the lectotype of B. bidens with a size of $0.98 \mathrm{~mm}$ is referred to.

Occurrence. Estonia: Haljala Stage (C3/D1) and Keila Stage (D2). Glacial erratic boulders: Harpa Lst. (D2; Krause's glacial erratic boulder no. 670, Ahl-1001); Baltic Backsteinkalk = Sandöflint (14B2 type, glacial erratic boulder 14B2, 1B341, Ho-2); Rollsteinkalk (glacial erratic boulder Ro-2 (D2); Lavenderblue Cherts (Hornsteine) of Sylt, types Sy-154 (D1), Sy-167 (C3/ D1), Sy-108 (Cyclocrinus Lst., D2).

Family Tetradellidae Swartz, 1936

Subfamily Sigmoopsinae Henningsmoen, 1953

\section{Kiesowia Ulrich \& Bassler, 1908}

Type species. Beyrichia dissecta Krause, 1892; by original designation.

Definition. Quadrilobate, lobes disintegrated into single nodes. Each node is composed of two nodes. Females anteriorly and ventrally with an undulate velar flange. A shorter histial ridge may branch off from the velar flange anterocentrally and may extend to the centroventral region. Marginal sculpture developed as a row of spines. Surface with spines and granules. 


\section{Kiesowia dissecta (Krause, 1892)}

Figure 2B-D

1892 Beyrichia dissecta Krause: 391-393, 398-399, pl. 21, fig. 3. 1892 Beyrichia mamilosa Krause: 386, 393, 399, pl. 22, fig. 14.

1894 Tetradella ? dissecta, Tetradella ? mamillosa. - Ulrich: 679.

1908 Tetradella (Kiesowia) dissecta, T. (K.) mamillosa. - Ulrich \& Bassler: 306-307, pl. 39, figs 10-11 (after Krause).

1923 Kiesowia (Beyrichia) dissecta. - Ulrich \& Bassler: 311, fig. 20.6 (presumably after Krause 1892: pl. 21, fig. 3).

1934 Kiesowia mamillosa. - Bassler \& Kellett: 349-350 (partim), 481.

1951 Kiesowia mamillosa, Kiesowia dissecta. - Kesling: 157-158, pl. 4 , fig. 3 , pl. 5 , fig. 3 .

1954b Kiesowia dissecta $=$ ? Kiesowia mamillosa.- Henningsmoen: 76, 78-80, 101, pl. 2, figs 1-3, 5 .

1956 Kiesowia septenaria Stumbur: 188-189, 194, pl. 2, fig. 1.

1958 Kiesowia dissecta. - Pokorný: 138, fig. 667 (after Krause).

1962 Kiesowia dissecta. - Sarv: 95, 97-98, 103, 109-111, 127, tab. 1 , pl. 4 , fig. 9 .

1965 Kiesowia dissecta. - Pokorný: 145.

1967 Hithis leviconvexus Schallreuter: 619-621, fig. 3.

non 1970 Kiesowia mamillosa. - Schallreuter: 288 (= ? Homeokiesowia frigida, Schallreuter 1976: 178).

1977 Kiesowia dissecta. - Helmdach: fig. 18.

1979 Kiesowia (Kiesowia) dissecta. - Schallreuter: 79, 81, 83, 85, pl. 6, 80, figs $1-4$, pl. 6 , 82, figs $1-4$, pl. 6, 84, figs $1-5$, pl. 6 , 86 , figs $1-6$.

1982 Hithis ? mamillosa. - Schallreuter \& Siveter: 87.

1986 Kiesowia (Kiesowia) dissecta. - Schallreuter: 7, 22, pl. 4, fig. 4. 1987b Kiesowia (Kiesowia) dissecta. - Schallreuter: 207, 222.

1988a Kiesowia (Kiesowia) dissecta. - Schallreuter: 1042, 1045, pl. 1 , fig. 7.

1990 Kiesowia dissecta. - Abushik in Abushik et al.: 61, 233, pl. 7, fig. 10.

1992 Kiesowia mamillos $a=K$. septenaria - Sidaravičienė: 52-54, 233, tab. 2, (non pl. 12, fig. 3, see below).

1996 Kiesowia dissecta. - Meidla: 56-57, tabs 5, 9, figs 9-10, 20 (faunal logs), pl. 10, fig. 3.

1998 Kiesowia dissecta. - Hinz-Schallreuter \& Schallreuter: fig. 85b.

Synonyms. K. mamillosa and K. septenaria Stumbur, 1956 have been considered as (possible) synonyms of $K$. dissecta (Henningsmoen 1954b: 79-80; Sarv 1962: 109-110; Meidla 1996: 57). Meidla (1996: 57) regarded also Hithis leviconvexus as a synonym of Kiesowia dissecta. Schallreuter (1979: 85) had already assumed that K. mamillosa is a senior synonym of $H$. leviconvexus.

Lectotype of Beyrichia dissecta: tecnomorphic right valve, MB. HS 2010-3 - Figure 2B; Krause 1892, pl. 21, fig. 3.

The part of the valve anteriorly of the fine crack seen at Krause's figure is broken away later (Meidla 1996: 57). The valve was still complete when Heidrich prepared a drawing of the valve (Helmdach 1977, fig. 18).

Type locality and horizon. Müggelheim; Krause's glacial erratic boulder no. 616, age: upper Upper Ordovician, presumably Porkuni (F2).

Holotype of Beyrichia mamillosa (monotypy). right tecnomorphic valve, MB. HS 2010-4 - Figure 2D; Krause 1892, pl. 22, fig. 14 Müggelheim, Berlin; Krause's glacial erratic boulder no. 667, a yellowish crystallinic glacial erratic boulder with Primitia elongata Krause, 1891.

Holotype of Kiesowia septenaria. left tecnomorphic valve, Tartu Os 5005 - Stumbur 1956, pl. 2, fig. 1, Sarv 1962, pl. 4, fig. 9. Porkuni, F2.

Holotype of Hithis leviconvexus. right female valve, GG 25-3 Schallreuter 1967, fig. 3. Isle of Gotland (Baltic Sea), Öjlemyrflint (glacial erratic boulder no. 794), F1c/F2.
Dimensions. Holotype of $K$. dissecta L $>2.05 \mathrm{~mm}, \mathrm{H}$ $1.22 \mathrm{~mm}$; holotype of $K$. mamillosa L $1.15 \mathrm{~mm}, \mathrm{H}$ $0.61 \mathrm{~mm}$; holotype of K. septenaria L $2.40 \mathrm{~mm}$ (Stumbur 1956: 188) or $1.70 \mathrm{~mm}$ (Sarv 1962: 109); holotype of Hithis leviconvexus L $1.20 \mathrm{~mm}, \mathrm{H} 0.79$ (incl. velar flange).

Definition. Females 1.20-2.15 mm (Sarv 1962: 109), ? $2.40 \mathrm{~mm}$. Histium short or completely missing.

Comparison. K. prussica Schallreuter, 1987 (1.66$2.35 \mathrm{~mm}$ ) has a histial ridge which extends further posteriorly than in $K$. dissecta and may reach the ventral end of L3 (Schallreuter 1987b, pl. 1b, fig. 1; Sarv 1959, pl. 21, fig. 17; Sidaravičienè 1992, pl. 12, figs 3-5).

Remarks. Kiesowia dissecta is quadrilobate with the lobes split into single nodes with each being composed of two nodes. L1 is represented by the anterocentral node $(\mathrm{L} 1 \mathrm{~m})$ and a less distinct, smaller anterodorsal node or spine (L1d). The anteroventral node has been often considered as the ventral node of L1 (L1v) but represents in fact the ventral node of L2 (L2v). L2 consists of L2m and L2v. Since L1m is usually fused with $\mathrm{L} 2 \mathrm{v}$, the latter has been often misinterpreted as anteroventral node of L1 (L1v) and made Henningsmoen (1954b: 79) state “... L1 tends to split into three nodes. This is especially seen in larval valves". However, as lobes in their dorsoventral extend are generally forwardly directed, the above interpretation would lead to a posteriorly directed extend of L1.

In palaeocopes, females are usually more important for taxonomic determinations than tecnomorphs. Specimens of $K$. dissecta with frill (= females) were firstly figured by Henningsmoen (1954b, pl. 2, figs $2-3$, L 1,89 - 2.04, according to magnification). Additional and better preserved material was provided by Schallreuter (1979) in the Stereo-Atlas of Ostracod Shells. The figured females are smaller $(1.43-1.58 \mathrm{~mm})$ but all with fused $\mathrm{L} 1 \mathrm{~m} / \mathrm{L} 2 \mathrm{v}$. In these specimens the frill has the same extent (posteriorly up to L4v) like in the valves figured by Henningsmoen. Therefore, they must be considered as adults and accordingly may represent a new, smaller (older ?) subspecies (Schallreuter 1979: $85)$.

By contrast, in Hithis leviconvexus the frill terminates posteriorly already ventrally of L3v. The smaller size and the development of three anterior nodes with $\mathrm{L} 1 \mathrm{~m}$ not being fused with $\mathrm{L} 2 \mathrm{v}$ could be interpreted as larval feature. Also the shorter velar frill may be a larval character as, e.g, in tecnomorphs of Piretella triebe$l i$ and Laccochilina lateris (Schallreuter 1975: 165, 173, pl. 3, fig. 5, pl. 5, fig. 2). However, since the antrum is fully developed with a flange-like inner antral fence (Fig. 2C), which indicates that it is an adult and not a pre-adult female. In typical specimens of $K$. dissecta the inner antral fence is formed by a row of spines having their distal portion connected by a thin horizontal bar (Schallreuter 1979, pl. 6, 80, figs 2-3, pl. 6, 82, fig. 3). Taxonomically, Hithis leviconvexus is 
therefore, considered here as a subspecies of $K$. dissecta because of the differences not only in size.

Sidaravičienè (1992: 53-54) considered K. mamillo$s a$ as a separate species characterized by the distinct L1m. Her figured K. mamillosa (Sidaravičienè 1992, pl. 12, fig. 3) as well as her $K$. sp. A (Sidaravičienè 1992, fig. 4) both belong to K. prussica. The development or lack of $\mathrm{L} 1 \mathrm{~m}$ is merely a matter of variation (see above). K. prussica is characterized by its distinct histium, while in $K$. dissecta the histium is usually lacking; if present at all, it is only short (Schallreuter 1979, pl. 80, fig. 1). The specimens of $K$. prussica figured as $K$. mamillosa, $K$. sp. A and $K$. sp. B by Sidaravičienè (1992, pl. 12, figs 3-5) have differently long developed histia and represent the variation range of $K$. prussica. Already Sidaravičienè (1992: 55) assumed intraspecific variation concerning the very short histium in $K$. sp. B.

Occurrence. Oslo region: 5a-b. Estonia: Nabala Stage - Tamsalu Fm. (F1 - G2). Lithuania: ? Vormsi Stage - ? Pirgu Stage. Glacial erratic boulders: Öjlemyr flint and upper Ordovician limestones.

The occurrence in Lithuania is questionable. Meidla (1996: 57) mentioned the occurrence in Vormsi Stage and ? Pirgu Stage but Sidaravičienè (1992: 54) listed only one specimen of $K$. cf. dissecta from the Vormsi Stage. It seems that $K$. dissecta is in the Baltic region restricted to the North Estonian confacies belt. In size the lectotype is conform with the Estonian material. The smaller material considered as a possible subspecies (see above) occurs more westernly in the northern Middle Baltic Sea.

Suborder Binodicopa Schallreuter, 1972

Superfamily Drepanelloidea Ulrich \& Bassler, 1923

Family Drepanellidae Ulrich \& Bassler, 1923

\section{Duplexibollia Schallreuter, 1987}

Type species. Bollia duplex Krause, 1892; by original designation.

Remarks. The genus is presently monotypic. By contrast, Sidaravičienè (1992: 158) considered Duplexibollia duplex sensu Schallreuter (1987a) as a different species, which would be a case of "misidentified type species" according to ICZN art. 70.3. Only for this case Duplexibollia duplex sensu Schallreuter (1987a) should be suggested as type species instead of Krause's species (but see also "comparisons").

Definition. Large, outline amplete or subamplete. Quadricristate with two broad, lobe-like, u-shaped cristae parallel to free margin and separated from the latter by a u-shaped furrow. Inner crista ventrally of S2 reduced. Marginal border flattened and with short spines.

\section{Duplexibollia duplex (Krause, 1892)}

Figure 1C

1892 Bollia duplex Krause: 386, 389, 392, 399, pl. 21, fig. 7.

1954b Bollia duplex. - Henningsmoen: 75, 86, 97-99, 101, pl. 2, figs $6-7$. 1987a Duplexibollia duplex. - Schallreuter: 39-40, fig. 3.3.

1990 Duplexibollbia duplex. - Meidla et al. in Aru et al.: fig. 28 (faunal $\log )$.

1992 Duplexibollia duplex. - Sidaravičienè: 157-158, 245, tab. 2, pl. 39, figs 7-8.

1996 Duplexibollia duplex. - Sidaravičienè: 41, 57, tab. 12, figs 5-6, 9 (faunal $\log$ s).

Holotype (monotypy, not lectotype as given by Henningsmoen 1954b: 98). Anteriorly incomplete left valve, MB. HS 2010-15, Figure 1C; Krause 1892, pl. 21, fig. 7.

Type locality and horizon. Müggelheim; Krause's glacial erratic boulder no. 640, a yellow-whitish glacial erratic boulder together with Platybolbina distans and Cystomatochilina umbonata, age Nabala, Vormsi or Pirgu Stage after the occurrences of Cystomatochilina umbonata and Duplexibollia duplex in Estonia and Lithuania (Meidla 1996: 25; Sidaravičienè 1992: 158; Sidaravičienè 1996, tab. 2).

Dimensions and proportions (L, H in mm, L : H). Holotype $2.75-1.59-1.73$. Carapaces Sidaravičienè 1992, 245, pl. 39, figs 7-8) heteromorph $3.00-1.85-$ 1.62, tecnomorph $2.75-1.60-1.72$. Left valve (Schallreuter 1987a, fig. 3.3) $2.37-1.45$ - 1.63 (domicilium 2.27 - 1.36 - 1.68). Henningsmoen 1954b, left valves pl. 2 figs $6-7: 2.33-1.33-1.75,2.40-1.52$ -1.58 (according to magnification).

Definition. As for the genus.

Remarks. Sidaravičienė (1992: 157-158, pl. 39, figs 78) mentioned sexual dimorphism in Duplexibollia $d u$ plex which is expressed by the development of a narrow restricted velum extending from the anterior cardinal corner to the posteroventral region and not covering the free margin. However, what Sidaravičienè considered as velum seems to be merely the result of an ontogentically increasing development of the adjacent semifurrow. Therefore, Duplexibollia is not a dimorphic taxon. Her arguments are not convincing. The "velum" (pseudovelum) which is present in few large valves only seems to be more a function of the strength of development of the neighbouring furrow which seems to be dependant from the ontogeny.

Sidaravičienè (1992: 158) considered D. duplex Schallreuter, 1987 from the Öjlemyr flint boulder no. G287 from the Isle of Gotland as a possible new species, which is distinct from Krause's species by a small adductorial lobe, an interrupted inner connecting lobe, the occurrence of marginal tubercles, and the more distinct cardinal corners (cf. Schallreuter 1987a, fig. 3.3; Sidaravičiene 1992, pl. 39, figs 7-8). Since the above outlined differences are only a matter of ontogenesis, Sidaravičienè's respective interpretation is also declined.

Occurrence. Oslo region: Oslo-Asker (Hovedøva): 5b, Ringerike (Frognøy, Stavnestangen): 5a (Henningsmoen 1954b: 99); Estonia: Saunja Fm., Nabala Stage (Meidla et al. in Aru et al. 1990, fig. 28); Lithuania: Pirgu (F1c), Nadtaučionys [ upper F2 (Sidaravičienè 1992: 158), or uppermost Pirgu or Tommarp (Sidaravičienė 1996, tab. 2)]. Glacial erratic boulders: Öjlemyr flint of the Isle of Gotland (Schallreuter 1987a), type locality. 
Order Podocopa Sars, 1866

Suborder Metacopa Sylvester-Bradley, 1961 emend. Adamczak, 1967

Superfamily Bairdiocypridoidea Shaver, 1961

Family Balticellidae Schallreuter, 1968

\section{Balticella Thorslund, 1940}

Type species. Balticella oblonga Thorslund, 1940; by original designation.

= Primitia globifera Krause, 1892 = Primitia binodis Krause, 1897

Definition. Schallreuter 1968: 135

\section{Balticella globifera (Krause, 1892)}

Figure 2G-H

1892 Primitia (Ctenobolbina?) globifera Krause: 389-390, 399, pl. 22, fig. 9.

1897 Primitia binodis Krause: 934, 938, pl. 25, fig. 16.

1934 Kloedenia globifera. - Bassler \& Kellett: 70, 362, 444.

1940 Hesperidella globifera. - Thorslund: 179 (partim); non 179 (partim), 187, pl. 3, fig. 12, pl. 5, fig. $6=$ H. esthonica (Bonnema, 1909)

1940 Balticella oblonga Thorslund: 49, 180, 187, pl. 1, figs 18-20.

1941 Ctenentoma binodis. - Schmidt: 35-37.

1962 Hesperidella sp. indet. - Jaanusson: 413.

1964 Balticella binodis $=$ B. oblonga . - Schallreuter: 95 .

1968 Balticella binodis. - Schallreuter: 135-137, fig. 10 (syn.).

1973 Balticella binodis. - Neben \& Krueger: pl. 95, fig. 4 (= Schallreuter 1968, fig. 10.4).

1976 Balticella binodis. - Jaanusson: 312-313, fig. 9 (faunal log, no. 42).

1985 Balticella binodis. - Schallreuter \& Siveter: pl. 69, fig. 4 (= Schallreuter 1968, fig. 10.4)

1990 Balticella binodis. - Schallreuter: 278, pl. 7, fig. 8.

1992 Balticella binodis. - Sidaravičienè: 195, 249, tab. 2, pl. 51, figs $1-2$.

Holotype (monotypy). Steinkern and external mould of a juvenile right valve, MB. HS 2010-16, Krause 1892, pl. 22, fig. 9 (steinkern), Figure 2.8 (external mould).

Among the material, which came back from Uppsala to Berlin by the end of the 1990s, the respective slide with the holotype (steinkern) of Balticella globifera was empty due to the broken cover glass. However, the glass tube from which the steinkern had been removed in order to store it in a slide still contained the - dorsally incomplete - external mould of the specimen, which is now the holotype.

Type locality and horizon. Müggelheim, Krause's glacial erratic boulder no. 666, age presumably Haljala Stage (C3/D1) or Keila Stage (D2)

Dimension. Length of holotype $0.85 \mathrm{~mm}$.

Definition. See definition of Balticella binodis, Schallreuter 1968: 135.

Comparisons. With the placement of Primitia globifera in Kloedenia, Bassler \& Kellett (1934: 362) were closer to the truth than later Thorslund (1940) and Jaanusson (1957, 1962) with their determination as a species of Hesperidella.

Thorslund (1940: 179) considered Primitia globifera and Primitia esthonica as synonyms, which became, however, never accepted. Despite his assumption that "... these species may be identical...", Jaanusson (1957: 329) regarded H. globifera as a nomen dubium, also after having studied the holotype (not lectotype) (Jaanusson 1962: 413).

Reinvestigation of the holotype clearly shows that it belongs to Balticella binodis (= B. oblonga), which is characterized by both PAN and a posterior tubercle or spine. This species was erected by Krause 1897 who did not realize the synonymy with his previous Primitia globifera (Krause, 1892) (Fig. 2G). By contrast, in the external mould of the holotype of B. globifera a spine is not visible. It is uncertain whether the posterodorsal part including the spine or only the spine itself is primarily lacking. However, the spine proved to be variable in both strength and position (Schallreuter 1968, fig. 10). In the largest valve ( $\mathrm{L} 1.65 \mathrm{~mm}$ ) it is only tubercle-like and situated posterocentrally in height of the central portion of the PAN. In smaller specimens the spine is stronger and located in height of the dorsal part of the PAN. Thorslund (1940: 180, pl. 1, figs 1820) neither described nor figured a spine in B. oblonga but mentioned "... small tubercles, sometimes with a larger one on the antero-dorsal slope" from his vice versa orientated valves.

The holotype is very weakly reticulogranulated. The surface ornamentation varies in this species between nearly smooth and granulated with some scattered tubercles (Schallreuter 1968, fig. 10; Schallreuter 1990, pl. 7, fig. 8).

Occurrence. B. globifera is known from outcrops in Sweden (Kinnekulle, Fjäcka, Central Lockne Area) from the Ludibundus beds and the Skagen Limestone and borings from Lithuania from the Jõhvi stage. The best material came from glacial erratic boulders of Tvären and Backsteinkalk glacial erratic boulders of Northern Central Europe (Swedish, Baltic and intermediate types).

\section{Epilogue}

In many cases Krause's drawings were considered of bad quality or "... somewhat diagrammatic" (Jaanusson 1962: 412). However, reinvestigation of his original material with SEM stereotechnique revealed, that Krause recognized almost all relevant characters of the respective taxa except for fine surface ornamentations. Apart from the latter, his illustrations are still informative and suitable for taxonomic work. Already assumed synonymy of many new taxa later described from outcrops, borings and also glacial erratic boulders based on Krause's illustrations could be verified by the present study.

\section{Acknowledgements}

The material was kindly made available for restudy by D. Lazarus, Museum für Naturkunde, Berlin. We thank Tõnu Meidla, Tartu, and an anonymous reviewer for their valuable comments on the manuscript. 


\section{References}

Abushik, A. F., Gusseva, E. A., Ivanova, V. A., Kanygin, A. V., Kashevarova, N. P., Melnikova, L. M., Molostovskaja, I. I., Neustrueva, I. Ju., Sidaraviciene, N. V., Stepanaitys, N. E., Tschigova, V. A., Gorak, S. V. \& Sarv, L. I. 1990. Ostrakody paleozoja (Paleozoic Ostracoda). - Prakticheskoe rukovodstvo po mikrofaune SSSR 4: $1-356$.

Adamczak, F. 1967. Morphology of Two Silurian Metacope Ostracodes from Gotland. - Geologiska Föreningens i Stockholm Förhandlingar 88: 462-475.

Agnew, A. F. 1942. Bibliographic Index of New Genera and Families of Paleozoic Ostracoda Since 1934. - Journal of Paleontology 16 (6): 756-763.

Andersson, J. G. 1893. Ueber das Alter der Isochilina canaliculataFauna. - Öfversigt af Kongliga Vetenskaps-Akademiens Förhandlingar 1893 (2): 125-129.

Aru, H., Bauert, H., Einasto, R., Hints, L., Jürgenson, E., Kaljo, D., Klaamann, E., Kórts, A., Meidla, T., Mägi, S., Männik, P., Männil, Ra., Männil, Re., Märss, T., Nestor, H., Nestor, V., Noor, A., Nólvak, J., Puura, I., Puura, V., Rubel, M., Darv, L., Tiismaa, R. \& Viira, V. 1990. In Kaljo, D. \& Nestor, H. (eds). Field Meeting Estonia 1990. An Excursion Guidebook. Estonian Academy of Sciences, Tallinn: pp. 1-209.

Bassler, R. S. \& Kellett, B. 1934. Bibliographic Index of Paleozoic Ostracoda. - Geological Society of America Special Papers 1: 1500.

Benson, R. H., Berdan, J. M., Bold, W. A. van den, Hanai, T., Hessland, I., Howe, H. V., Kesling, S. A., Levinson, S. A., Reyment, R. A., Moore, R. C., Scott, H. W., Shaver, R. H., Sohn, I. G., Stover, L. E., Swain, F. M. \& Sylvester-Bradley, C. 1961. Systematic Descriptions. In Moore, R. C. \& Pitrat, C. W. (eds). Treatise on Invertebrate Paleontology Q: Arthropoda 3, Crustacea Ostracoda. Geological Society of America, New York: pp. 99-421.

Bock, J. 1867. Über Beyrichia Grewingkii. - Neues Jahrbuch für Mineralogie, Geologie und Palaeontologie 1867 (5): 592-593.

Bonnema, J. H. 1909. Beitrag zur Kenntnis der Ostrakoden der Kuckersschen Schicht (C2). - Mitteilungen aus dem MineralogischGeologischen Institut der Reichs-Universität zu Groningen aus den Gebieten der Kristallographie, Mineralogie, Petrographie, Geologie und Palaeontologie 2 (1): 1-84.

Brögger, W. C. 1882. Die silurischen Etagen 2 und 3 im Kristianiagebiet und auf Eker, ihre Gliederung, Fossilien, Schichtenstörungen und Contactmetamorphosen. Universitätsprogramm für 2. Semester 1882. A. W. Brögger, Kristiania.

Diebel, K. 1960. Die paläontologischen Originale der Berliner Museen. - Paläontologische Zeitschrift 34: 59-60.

Döderlein, L. 1913. Die Steinkorallen aus dem Golf von Neapel. Mitteilungen aus der zoologischen Station zu Neapel, zugleich ein Repertorium für Mittelmeerkunde 21 (5): 105-152.

Eichwald, E. 1854. Die Grauwackenschichten von Liev- und Esthland. - Bulletin de la Société Impériale des naturalistes de Moscou 27 (1): 3-111.

Eichwald, E. 1860. Lethaea Rossica ou paléontologie de la Russie 1 (Seconde Section de l'ancienne Période, contenant la continuation de la Faune de l'ancienne Période, savoir des Mollusques jusqu'aux Reptiles). Schweizerbart, Stuttgart.

Gailīte, L. 1973. Analiz rasprostraneniya i korrelyacionnoe znachenie trilobitov i ostrakod srednego ordovika Latvii (Distribution Analysis and Correlative Value of Middle Ordovician Trilobites and Ostracods in Latvia) - Problemy regional'noj geologii Pribaltiki i Belorussii 1973: 63-70.

Harris, R. W. 1931. Description of Ostracodes and Conodonts. - Oklahoma Geological Survey Bulletin 55: 87-95.

Helmdach, F.-F. 1977. Leitfaden zur Bestimmung fossiler und rezenter Ostrakoden. De Gruyter, Berlin/New York.
Henningsmoen, G. 1948. The Tretaspis Series of the Kullatorp Core. - Bulletin of the Geological Institution of the University of Upsala 32: $374-432$.

Henningsmoen, G. 1953a. The Middle Ordovician of the Oslo Region, Norway 4. Ostracoda. - Norsk Geologisk Tidsskrift 32 (1): 35-56.

Henningsmoen, G. 1953b. Classification of Paleozoic Straight-Hinged Ostracods. - Norsk Geologisk Tidsskrift 31: 185-290.

Henningsmoen, G. 1954a. Lower Ordovician Ostracods from the Oslo Region, Norway. - Norsk Geologisk Tidsskrift 33 (1/2): 41-68.

Henningsmoen, G. 1954b. Upper Ordovician Ostracods from the Oslo Region, Norway - Norsk Geologisk Tidsskrift 33 (1/2): 69-108.

Henningsmoen, G. 1965. On Certain Features of Palaeocope Ostracodes. - Geologiska Föreningens i Stockholm Förhandlingar 86: 329-394.

Hessland, I. 1949. Investigations of the Lower Ordovician of the Siljan District, Sweden I. Lower Ordovician ostracods of the Siljan District, Sweden. - Bulletin of the Geological Institution of the University of Upsala 33: 97-408.

Hinz-Schallreuter, I. \& Schallreuter, R. 1998. Ostrakoden. HaeckelBücherei 4. Enke, Stuttgart.

Ivanova, V. A. 1979. Ostrakody rannego i srednego ordovika Podotryad Hollinomorpha. - Akademiya nauk SSSR Trudy Paleontologicheskogo instituta 172: 1-216.

Jaanusson, V. 1957. Middle Ordovician Ostracodes of Central and Southern Sweden. - Bulletin of the Geological Institutions of the University of Uppsala 37 (3/4): 173-442.

Jaanusson, V. 1960. The Viruan (Middle Ordovician) of Öland. - Bulletin of the Geological Institutions of the University of Uppsala $38(3 / 4)$ : 207-288.

Jaanusson, V. 1962. Remarks on the Ordovician ostracods Described by A.Krause. - Geologiska Föreningens Förhandlingar 83: 412-413.

Jaanusson, V. 1963. Lower and Middle Viruan (Middle Ordovician) of the Siljan District. - Bulletin of the Geological Institutions of the University of Uppsala 42 (1/6): 1-41.

Jaanusson, V. 1966. Ordovician Ostracodes with Supravelar Antra. Bulletin of the Geological Institutions of the University of Uppsala 43 (6/8): 1-30.

Jaanusson, V. 1976. Faunal Dynamics in the Middle Ordovician (Viruan) of Balto-Scandia. In Bassett, M. G. (ed.). The Ordovician System: proceedings of a Palaeontological Association symposium, Birmingham. University of Wales Press and National $\mathrm{Mu}-$ seum of Wales, Cardiff: pp. 301-326.

Jones, T. R. 1855. Notes on Palæozoic Entomostraca. No.I. Some Species of Beyrichia from the Upper Silurian Limestones of Scandinavia. - Annals and Magazine of Natural History, including Zoology, Botany, and Geology, Second Series 16 (92): 81-92.

Jones, T. R. \& Holl, H. B. 1865. Notes on the Palæozoic Bivalved Entomostraca. No. VI. Some Silurian Species (Primitia). - Annals and Magazine of Natural History including Zoology, Botany, and Geology, Second Series 16 (96): 414-425.

Kesling, R. V. 1951 Terminology of Ostracod Carapaces. - Contributions from the Museum of Paleontology University of Michigan 9 (4): 93-171.

Koken, E. 1896. Die Leitfossilien. Ein Handbuch für den Unterricht und für das Bestimmen von Versteinerungen. Tauchnitz, Leipzig.

Krause, A. 1889. Ueber Beyrichien und verwandte Ostracoden in untersilurischen Geschieben. - Zeitschrift der Deutschen geologischen Gesellschaft 41 (1): 1-26.

Krause, A. 1891. Beitrag zur Kenntnis der Ostrakoden-Fauna in silurischen Diluvialgeschieben. - Zeitschrift der Deutschen geologischen Gesellschaft 43 (2): 488-521.

Krause, A. 1892. Neue Ostrakoden aus märkischen Silurgeschieben. Zeitschrift der Deutschen geologischen Gesellschaft 44 (3): $383-$ 399

Krause, A. 1897. Ueber die Ostrakodenfauna eines holländischen Silurgeschiebes. - Zeitschrift der Deutschen geologischen Gesellschaft 48 (4): 932-939. 
Kummerow, E. 1924. Beiträge zur Kenntnis der Ostracoden und Phyllocariden aus nordischen Diluvialgeschieben. - Jahrbuch der Preußischen Geologischen Landesanstalt 44: 405-448.

Kummerow, E. 1933. Zur Paläobiologie der Ostrakoden und Trilobiten. - Centralblatt für Mineralogie, Geologie und Paläontologie Abteilung B 1933 (1): 42-53.

Kummerow, E. 1939. Die Ostrakoden und Phyllopoden des deutschen Unterkarbons. - Abhandlungen der Preußischen Geologischen Landesanstalt, Neue Folge 194: 1-107.

Laškov, E., Paškevičius, J. \& Sidaravičiene, N. 1984. Litostratigrafiya ordovikskich otlozhenij Sredne-Litovskogo progiba. In Männil, R. M. \& Mens, K. A. (eds). Stratigrafiya drevnepaleozojskich otlozhenij Pribaltiki. Akademii Nauk Estonskoj SSR, Tallin: pp. 77-93.

Linnarsson, J. G. O. 1869. Om Vestergötlands Cambriska och Siluriska aflagringar. - Kongliga Svenska Vetenskaps-Akademiens Handlingar 8 (2): 1-89.

McCoy, F. 1851. A Synopsis of the Classification of the British Palæozoioc Rocks, with a Systematic Description of the British Palæozoic Fossils in the Geological Museum of the University of Cambridge. First Fasciculus. John W. Parker \& Son, London.

Meidla, T. 1996. Late Ordovician Ostracodes of Estonia. - Fossilia Baltica 2: 1-222.

Miller, S. A. 1889. North American Geology and Palæontology for the Use of Amateurs, Students, and Scientists. Western Methodist Book Concern, Cincinnati, Ohio.

Neben, W. \& Krueger, H. H. 1973. Fossilien ordovicischer und silurischer Geschiebe. - Staringia 2: $12 \mathrm{pp}$.

Neckaja, A. I. 1952. Novye vidy ostrakod iz otlozenij ordovika severo-zapadnoj casti Russkoj platformy. - Trudy Vsesoyuznogo neftyanogo nauchno-issledovatel'skogo geologorazvedochnogo instituta (VNIGRI), novaya seriya 60: 217-232.

Neckaja, A. I. 1953. Tetradellidy ordovika Pribaltiki i ikh stratigraficheskoe znachenie. - Trudy Vsesoyuznogo neftyanogo nauchnoissledovatel'skogo geologorazvedochnogo instituta (VNIGRI), novaya seriya 78 : $309-383$.

Neckaja, A. I. 1958. Novye vidy i rody ostrakod ordovika i silura severo-zapada Russkoj platformy. - Trudy Vsesoyuznogo neftyanogo nauchno-issledovatel'skogo geologorazvedochnogo instituta (VNIGRI), novaya seriya 115: 349-379.

Neckaja, A. I. 1966. Ostrakody ordovika i silura SSSR (semejstva Schmidtellidae, Rectellidae, Longisculidae i nekotorye novye vidy drugich semejstv). - Trudy Vsesoyuznogo neftyanogo nauchno-issledovatel'skogo geologorazvedochnogo instituta (VNIGRI) 251: $1-104$.

Neckaja, A. I. 1973. Ostrakody ordovika i silura SSSR. - Vsesoyuznyj neftyanoj nauchno-issledovatel'skij geologorazvedochnyj institut Trudy 324: 1-104.

Olempska, E. 1989a. Moijczella, A New Genus of Ostracoda from the Ordovician of the Świetokrzyskie Mts., Poland. - Acta Palaeontologica Polonica 33 (2): 135-144.

Olempska, E. 1989b. Gradual evolutionary transformations of ontogeny in an Ordovician ostracod lineage. - Lethaea 22 (2): 159168.

Olempska, E, 1994. Ostracods of the Mójcza Limestone. - Palaeontologia Polonica 53 (1): 129-212.

Öpik, A. 1935. Kukruse lademe ostrakoodidest. - Eesti Loodus 3: 86-87.

Öpik, A. 1937. Ostracoda from the Ordovician Uhaku and Kukruse formations of Estonia. - Tartu ülikooli j.o. loodusuurijate seltsi aruanded 43 (1/2): 65-138.

Pokorný, V. 1958. Grundzüge der zoologischen Mikropaläontologie 2. Deutscher Verlag der Wissenschaften, Berlin.

Pokorný, V. 1965. Principles of Zoological Micropalaeontology 2. International Series of Monographs on Earth Sciences 20: 1-466.

Sars, G. O. 1866. Oversigt af Norges Marine Ostracoder. - Norske Forhandlingar i Videnskabs-Selskabet I Christiania 1865: 1-130.
Sarv, L. I. 1959. Ostrakody ordovika Estonskoj SSR (Ordovician Ostracods in the Estonian S.S.R.). - Eesti NSV Teaduste Akadeemia Geoloogia Instituudi Uurimused 4: 1-211.

Sarv, L. I. 1962. Ostrakody porkuniskogo gorizonta i llandoveri v Estonii (Ostracods from the Porkuni Stage and Llandovery of Estonia). - Eesti NSV Teaduste Akadeemia Geoloogia Instituudi uurimused 9: 95-141

Sarv, L. I. 1963. Novye vidy ostrakody ordovika Pribaltiki (New Ostracods from the Ordovician of East Baltic). - Eesti NSV Teaduste Akadeemia Geoloogia Instituudi Uurimused 13: 161-188.

Schallreuter, R. 1964. Eine neue Ostracodenunterfamilie, -Gattung und -Art der Familie Primitiopsidae aus einem mittelordovizischen Geschiebe Norddeutschlands. - Berichte der Geologischen Gesellschaft in der Deutschen Demokratischen Republik (Sonderheft) 2: 95-101, 148-149.

Schallreuter, R. 1965. Neue Ostracoden aus mittelordovizischen Backsteinkalkgeschieben. - Berichte der Geologischen Gesellschaft in der Deutschen Demokratischen Republik 10 (4): 479-487, 504509 .

Schallreuter, R. 1967. Neue Ostracoden aus ordovizischen Geschieben. - Geologie 16 (5): 499, 615-631.

Schallreuter, R. 1968. Ordovizische Ostracoden mit geradem Schloßrand und konkavem Ventralrand. - Wissenschaftliche Zeitschrift der Ernst-Moritz-Arndt-Universität Greifswald (Mathematisch-naturwissenschaftliche Reihe) 17 (1/2): 127-152.

Schallreuter, R. 1970. Alter und Heimat der Backsteinkalkgeschiebe. - Hercynia, Neue Folge 6 (3): 285-305.

Schallreuter, R. 1972. Drepanellacea (Ostracoda, Beyrichicopida) aus mittelordovizischen Backsteinkalkgeschieben IV. Laterophores hystrix sp.n., Pedomphalella germanica sp.n. und Easchmidtella fragosa (Neckaja). - Berichte der Deutschen Gesellschaft für Geologische Wissenschaften A 17 (1): 5, 139-145, 165-166.

Schallreuter, R. 1973. Tvaerenellidae (Ostracoda, Palaeocopina) aus Backsteinkalk-Geschieben (Mittelordoviz) Norddeutschlands. Palaeontographica A 144 (1/3): 55-111.

Schallreuter, R. 1975. Palaeocopine Ostrakoden aus BacksteinkalkGeschieben (Mittelordoviz) Norddeutschlands (mit Ausnahme der Tvaerenellidae, Ctenonotellidae und Tetradellidae). - Palaeontographica A 149 (4/6): 139-192.

Schallreuter, R. 1976. Ctenonotellidae (Ostracoda, Palaeocopina) aus Backsteinkalk-Geschieben (Mittelordoviz) Norddeutschlands. Palaeontographica A 153 (4/6): 161-215.

Schallreuter, R. 1979. On Kiesowia (Kiesowia) dissecta (Krause). - A Stereo-Atlas of Ostracod Shells 6 (2) 16: 79-86.

Schallreuter, R. 1982.On Bilobatia serralobata Schallreuter. - A Stereo-Atlas of Ostracod Shells 9 (1) 2: 9-16.

Schallreuter, R. 1983a. Glossomorphitinae und Sylthinae (Tetradellidae, Palaeocopa, Ostracoda) aus Backsteinkalk-Geschieben (Mittelordoviz) Norddeutschlands. - Palaeontographica A 180 (4/6): 126-191.

Schallreuter, R. 1983b. On Bromidella sarvi Schallreuter. - A StereoAtlas of Ostracod Shells 10 (1) 6: 25-28.

Schallreuter, R. 1983c. On Femerensia gealbertii gen. et.sp. nov. - A Stereo-Atlas of Ostracod Shells 10 (2) 15: 91-94.

Schallreuter, R. 1984a. Geschiebe-Ostrakoden I. - Neues Jahrbuch für Geologie und Paläontologie Abhandlungen 169 (1): 1-40.

Schallreuter, R. 1984b. Middle Ordovician ostracodes from Sweden. Geologiska Föreningens i Stockholm Förhandlingar 106 (1): 9399.

Schallreuter, R. 1985. Aurel Krauses "Geschiebe mit Beyrichia rostrata" (Ostracoda; Ordoviz). - Mitteilungen aus dem Geologisch-Paläontologischen Institut der Universität Hamburg 59 (1): 99-135.

Schallreuter, R. 1986. Ostrakoden aus Öjlemyrflint-Geschieben von Sylt. In Hacht, U. von (ed.). Fossilien von Sylt 2. Verlag IngeMaria von Hacht, Hamburg: pp. 203-232

Schallreuter, R. 1987a. Geschiebe-Ostrakoden II. - Neues Jahrbuch für Geologie und Paläontologie, Abhandlungen 174 (1): 23-53. 
Schallreuter, R. 1987b. Ostrakoden aus ordovizischen Geschieben Westfalens I. - Geologie und Paläontologie in Westfalen 7: 15-29.

Schallreuter, R. 1988a. Homeomorphy, Phylogeny and Natural Classification: Case Studies Involving Palaeozoic Ostracods. - Developments in Palaeontology and Stratigraphy 11: 1041-1049.

Schallreuter, R. 1988b. Neue Muschelkrebse aus Geschieben: 3. Neue ordovizische Hollinomorpha. - Geschiebekunde aktuell 4 (2): $39-42$.

Schallreuter, R. 1990. Ostrakoden aus mittelordovizischen Hornsteinen von Sylt. In Hacht, U. von (ed.). Fossilien von Sylt 3. Verlag Inge-Maria von Hacht, Hamburg: pp. 255-279.

Schallreuter, R. 1993. Beiträge zur Geschiebekunde Westfalens II. Ostrakoden aus ordovizischen Geschieben II. - Geologie und Paläontologie in Westfalen 27: 3-273.

Schallreuter, R. 1994. Schwarze Orthocerenkalkgeschiebe. - Archiv für Geschiebekunde 1 (8/9): 491-540.

Schallreuter, R. 1995. Signakiella steusloffi (Ostracoda, Ordoviz). Geschiebekunde aktuell 11 (4): 127-129.

Schallreuter, R. 1997. Geschlechtsdimorphismus bei paläozoischen Ostrakoden. - Geologisches Institut der Universitaet zu Köln, Sonderveröffentlichungen 114: 373-407.

Schallreuter, R. \& Hinz-Schallreuter, I. 2005. Synonyme von Geschiebe-Ostrakoden I. - Archiv für Geschiebekunde 4(9): 601-608.

Schallreuter, R. \& Hinz-Schallreuter, I. 2007. Sexual dimorphism in two Ordovician ostracods from the Baltoscandian region and their phylogenetic significance. - GFF 129 (3): 239-244.

Schallreuter, R. \& Hinz-Schallreuter, I. 2008. Synonyme von Geschiebe-Ostrakoden II. - Archiv für Geschiebekunde 4 (12): 809-816.

Schallreuter, R. \& Krůta, M. 1984. The Baltoscandian ostracode genus Piretella in the Ordovician of Bohemia. - Neues Jahrbuch für Geologie und Paläontologie Monatshefte 1984 (11): 684-688.

Schallreuter, R. E. L. \& Siveter, D. J. 1982. On Hithis colonus Schallreuter \& Siveter sp. nov. - A Stereo-Atlas of Ostracod Shells 9 (2) $15: 85-88$.

Schallreuter, R. E. L. \& Siveter, D. J. 1985. Ostracodes across the Iapetus Ocean. - Palaeontology 28 (3): 577-598.

Schallreuter, R. E. L., Swanson, K. M. \& McKenzie, K. G. 1999. Sex in the Palaeozoic (Ostracoda, Palaeocopida). In Vaupel Klein, J. C von \& Schram, F. R (eds). Proceedings of the 4th International Crustacean Congress: The Biodiversity Crisis and Crustacea. Balkema, Amsterdam: pp. 513-518.

Schmidt, E. A. 1941. Studien im böhmischen Caradoc (Zahořan = Stufe). 1. Ostrakoden aus den Bohdalec-Schichten und über die Taxonomie der Beyrichiacea. - Abhandlungen der Senckenbergischen Naturforschenden Gesellschaft 454: 1-96.

Schmidt, F. 1858. Untersuchungen über die Silurische Formation von Ehstland, Nord-Livland und Oesel. - Archiv für die Naturkunde
Liv-, Ehst- und Kurlands. Erste Serie. Mineralogische Wissenschaften, nebst Chemie, Physik und Erdbeschreibung 2 (1): 1248.

Sidaravičienè, N.1976. Zonal'noe raschlenenie zizhnego i srednego ordovika Pribaltijskogo regiona po ostrakodam. - Sovetskaya Geologiya 1976 (8): 48-56.

Sidaravičienè, N. 1992. Ostrakody ordovika Litvy. Litovskij nauchnoissledovatel'skij geologo-razvedochnyj institut, Vilnius.

Sidaravičienė, N. 1996. Lietuvos ordoviko ostrakodai, biostratigrafija. Lietuvos Geologijos institutas, Vilnius.

Steusloff, A. 1895. Neue Ostrakoden aus Diluvialgeschieben von Neu-Brandenburg. - Zeitschrift der Deutschen geologischen Gesellschaft 46 (4): 775-778.

Stumbur, K. 1956. O faune ostrakod porkuniskogo gorizonta v Estonskoj SSR (Porkuni lademe ostrakoodidefaunast Eesti NSV-s.). Tartu Riikliku Ülikooli Toimetised (= Acta et Commentationes Universitatis Tartuensis) 42: 186-194.

Swartz, F. M. 1936. Revision of the Primitiidae and Beyrichiidae, with New Ostracoda from the Lower Devonian of Pennsylvania. Journal of Paleontology 10 (7): 541-586.

Sztejn, J. 1985. Malzoraczki ordowiku w pólnocno-wschodniej Polsce. - Biuletyn panstwowego instytutu geologicznego 350: 53-89.

Sztejn, J. 1989. Stratygrafia mikropaleontologiczna ordowiku Lubelszcyzny i zachodniej czesci obnizenia podlaskiego. - Biuletyn panstwowego instytutu geologicznego 363: 69-92.

Thorslund, P. 1940. On the Chasmops Series of Jemtland and Södermanland (Tvären). - Sveriges Geologiska Undersökning (C) 436: $1-193$.

Thorslund, P. 1948. The Chasmops Series of the Kullatorp Core. Bulletin of the Geological Institutions of the University of Upsala 32 : $343-373$.

Tinn, O. \& Meidla, T. 2003. Ontogeny and Thanatocoenosis of Early Middle Ordovician Palaeocope Ostracode Species Brezelina palmata (Krause, 1889) and Ogmoopsis bocki (Öpik, 1935). - Journal of Paleontology 77 (1): 64-72.

Ulrich, E. O. 1894. The Lower Silurian Ostracoda of Minnesota. Geology of Minnesota 3 (2): 629-693.

Ulrich, E. O. \& Bassler, R. S. 1908. New American Paleozoic Ostracoda. Preliminary Revision of the Beyrichiidæ, with Descriptions of New Genera. - Proceedings of the United States National Museum 35: 277-340.

Ulrich, E. O. \& Bassler, R. S. 1923. Paleozoic Ostracoda: Their Morphology, Classification and Occurrence. - Maryland Geological Survey, Silurian 8: 271-391.

Ul'st, R. Ž., Gailīte, L. K. \& Jakovleva, V. I. 1982. Ordovik Latvii. Zinatne, Riga.

Williams, M. \& Siveter, D. J. 1989. On Bromidella reticulata Harris. - A Stereo-Atlas of Ostracod Shells 16 (1) 1: 1-8. 